\title{
Productivity, nutrient use efficiency, energetics and bio-economics of winter maize in south India
}

\section{S R Salakinkop ( $\nabla$ salakinkopsr@uasd.in )}

University of Agricultural Sciences, Dharwad

Siddarta Hulamani

University of Agricultural Sciences, Dharwad

\section{Research Article}

Keywords: Bio-economics, energetic, fertility, grain, planting, RDF, winter maize, yield

Posted Date: April 2nd, 2021

DOI: https://doi.org/10.21203/rs.3.rs-364825/v1

License: (c) (1) This work is licensed under a Creative Commons Attribution 4.0 International License. Read Full License 


\title{
Productivity, nutrient use efficiency, energetics and bio-economics of winter maize in south India
}

\author{
Siddharth Hulmani $^{1 \bowtie}$ and S.R. Salakinkop ${ }^{1 凶}$ \\ ${ }^{1}$ Department of Agronomy, College of Agriculture, Dharwad, \\ University of Agricultural Sciences, Dharwad, Karnataka, India \\ ${ }^{\square}$ Email: siddharthhulmani@gmail.com and salakinkopsr@uasd.in
}

\begin{abstract}
Maize area is rapidly spreading in south India in response to rising demand from the poultry and fish feed industries. The planting of maize during winter season is necessary to increase the total area and production of maize. The present investigation encompassing different sowing windows with different fertility levels revealed that significantly higher winter maize productivity was achieved from first and second week of October planting along with application of $200 \%$ RDF(recommended dose of fertilizer) followed by $150 \%$ RDF. Planting of winter maize during first week of October recorded significantly higher grain yield (8786 kg $\left.\mathrm{ha}^{-1}\right)$ and stover yield (1220 kg ha $\left.{ }^{-1}\right)$ and was found on par with sowing during second week of October. Among fertility levels, significantly higher grain yield $\left(8320 \mathrm{~kg} \mathrm{ha}^{-}\right.$ ${ }^{1}$ ) and stover yield (1195 $\left.\mathrm{kg} \mathrm{ha}^{-1}\right)$ were recorded with application of $200 \% \mathrm{RDF}$ and was found on par with application of $150 \%$ RDF. Similarly higher dry matter production, more days for physiological maturity, higher accumulation of growing degree days, photo thermal units and heliothermal units were recorded from crop planted during first and second week of October along with application of either 200 $\%$ or $150 \%$ RDF. Further higher nutrient use efficiency was recorded from first and second week October planted crop along with lower fertility level (100\% RDF). Similarly significantly higher output energy, net energy and specific energy were higher from crop planted during first week of planting along with application of 200 $\%$ RDF. Also it recorded higher net returns and gross returns Whereas, energy use efficiency and energy productivity were higher with planting during first week of October along with application of $100 \%$ RDF.
\end{abstract}

Keywards: Bio-economics, energetic, fertility, grain, planting, RDF, winter maize, yield 


\section{Introduction}

The world's maize area is 192.50 million hectares, and it ranks first in production with 1,112.40 million metric tonnes. The leading producers are USA (32.61\%), followed by China (22.91\%), Brazil (9.42\%), European Union (8.41\%), Argentina $(5.41 \%)$ and India $(4.1 \%)^{1}$. After rice and wheat, it is India's third most popular crop. It is currently grown on 9.38 million hectares with a yield of 28.752 million metric tons ${ }^{2}$.Because of its photo-thermo-insensitive nature and highest genetic yield potential among cereals, maize is known as the "Queen of Cereals." . Corn is grown all year round in India, in most states, for a variety of purposes including food, feed, fodder, green cobs, sweet corn, baby corn, pop corn, and industrial goods. There are three distinct seasons for the cultivation of maize in India viz., Kharif, rabi in peninsular India and Bihar, and spring in northern India. Maize is predominantly a kharif season crop but in past few years winter maize has gained a significant place in total maize production in India ${ }^{3}$. Winter maize is grown on an area of $1.697 \mathrm{~m}$ ha with a production of 8.302 million metric tons and with a productivity of $4893 \mathrm{~kg} \mathrm{ha}^{-14}$. The predominant winter maize growing states are Bihar (26.3 \%), Tamil Nadu (13.1\%), Maharashtra (12.9\%), West Bengal (12.4 \%), Andra Pradesh $(9.5 \%)$, Telangana $(6.9 \%)$ and Karnataka $(6.4 \%)^{4}$. It has emerged as an important crop in the non- traditional areas. While the crop responds favorably to better crop management in both the kharif and winter seasons, the irregular rainfall pattern of the south-west monsoon interferes with timely field operations of the kharif season. Due to the lack of significant environmental impediments in winter, the desired field operations can be scheduled and carried out at the most suitable time. In addition, lack of any major diseases and insect pests in this season, are helping the crop to express its potential. There is therefore an enormous opportunity to increase the area under cultivation of winter maize for higher productivity ${ }^{3}$.

For winter maize, the best sowing date is essential so that the genotype grown can complete its life cycle under ideal environmental conditions. Planting at the beginning of the growing season is generally recommended. Sowing at the right time is critical for maximum yield, as a delay in the planting date would result in a linear decrease in grain and stover yields ${ }^{5}$. The amount of yield reduction caused by delayed sowing, on the other hand, varies by location. Hence experiment was conducted to explore the most congenial sowing period in Southern India. 
The availability of sufficient nutrient in the soil in available form for plant uptake determines crop plant growth and yield ${ }^{6}$. There are a several of other factors that influence winter maize production and productivity; however, fertiliser management is one of the most important factors influencing maize growth and yields. Early maize planting can improve grain yields significantly, but other practises such as fertility can also trigger the yield ${ }^{7}$.

In agriculture, energy usage has intensified as a result of increasing population, a limited supply of arable land, and a demand for a higher standard of living $^{8}$. It is critical to create a production system that uses less energy and produces more energy as output in the context of changing global climatic conditions and increasing energy demands ${ }^{9}$. In this experiment, all of the inputs and outputs were considered to be in the form of energy. Human labour, animal power, fertiliser, gasoline, and electricity are all used in some way in agricultural operations ${ }^{10}$.All the inputs supplied and output obtained is considered in the form of energy. Power, electricity, machinery, seeds, fertilisers, and chemicals account for a significant portion of the existing agricultural production system's energy supply. One of them is fertiliser control with care. Since, on the one hand, it accounts for more than half of the total input energy used in the maize production system in many cases, and on the other hand, it is the most important factor for proper plant growth and development. However, if it is used excessively in such cases, it can pollute rivers and streams, as well as cause greenhouse gas emissions. As a result, excessive deployment, wastes resources and money while also exacerbating environmental problems ${ }^{11}$. Fertilizers, with a energy equivalency of 51.5 percent, were found to have the highest rate of energy equivalency among all the inputs used in maize production ${ }^{12}$

Planting window is one of the non-monetary input. Planting a crop at the right time increases not only the biological yield but also the profitability. It is important to investigate the required level of fertility and planting window in order to achieve long-term sustainability in winter maize production

\section{Material and Methods}

\section{Experimental site}


During the winter season 2019-2020, a field experiment was conducted to investigate the response of winter maize to planting windows and fertility levels at the University of Agricultural Sciences, Dharwad (Karnataka), which is located at $15^{\circ} 26^{\prime} \mathrm{N}$ latitude and $75^{\circ} 07^{\prime} \mathrm{E}$ longitude with an altitude of $678 \mathrm{~m}$ above mean sea level (MSL). The research station is located in the Northern Transitional Zone (Zone-8), which is located halfway between the Western Hilly Zone (Zone-9) and the Northern Dry Zone (Zone-9) (Zone-3). The soil is classified as clay by the USDA soil textural classification table. The $\mathrm{pH}$ of the soil was 7.6, which was neutral. Available nutrients such as nitrogen were low (261 kg ha-1) and phosphorous (31.5 kg ha-1) and potassium (289 kg ha-1) were medium.

\section{Treatment details}

The experiment was conducted in a Factorial Randomized Complete Block Design (RCBD) with three replications and fifteen treatment combinations. Planting windows (1st week of October, 2nd week of October, 3rd week of October, 4th week of October, and 5th week of October) and fertility levels (100 percent recommended dose of fertiliser (RDF), 150 percent RDF, and 200 percent RDF) were used as factors in the experiment. The single cross maize hybrid used was Monsanto's 900 M Gold.

It is popular private sector hybrid legally available in the public domain as well as at Dept. of Agriculture Govt. of Karnataka for commercial maize cultivation. It is one of popular hybrid among the maize growing farmers and has been taken for agronomic experiment for optimizing planting dates and fertility in winter season of south India. Hence it comply with relevant institutional and national guidelines.

Monsanto India Pvt. Ltd. released 900-M Gold (Mon-26) maize hybrid and it is in public domain for cultivation as well as agronomic research on maize as it is registered in India vide notification no.2137(E) in INIDA GAZETTE dated 31-082010. Further it is in the list of maize cultivars released for cultivation in India during 2010. Since its release it is being used for commercial cultivation as well as agronomic research in India. Hence this material has been deposited at NBPGR, New Delhi, India. 


\section{Cultivation method}

To bring the soil to fine tilth, the field was ploughed once, followed by tillage with a cultivator and harrowed twice. After the previous crop was harvested, weeds and remaining residues were removed from the experimental field. The plots were set out according to the experiment's layout design. Seeds were planted at a $60 \mathrm{~cm} \mathrm{x}$ $20 \mathrm{~cm}$ spacing with a seed rate of $20 \mathrm{~kg}$ ha- 1 . With the aid of a marker, the lines were opened, and the seeds were hand-dibbled at a depth of $4-5 \mathrm{~cm}$ before being covered with soil. All other treatment plots, including control plots, had well decomposed FYM @ $10 \mathrm{t} \mathrm{ha}^{-1}$ incorporated into soil two weeks prior to planting.The nutrients viz., nitrogen, phosphorus and potassium were applied @ $150 \mathrm{~kg} \mathrm{~N} \mathrm{ha}^{-1}, 65 \mathrm{~kg} \mathrm{P}_{2} \mathrm{O}_{5} \mathrm{ha}^{-1}$ and $65 \mathrm{~kg} \mathrm{~K}_{2} \mathrm{O} \mathrm{ha}^{-1}$ for fertility level of $100 \% \mathrm{RDF}$. Similarly for $150 \% \mathrm{RDF}, 225 \mathrm{~kg} \mathrm{~N}, 97.5 \mathrm{~kg} \mathrm{P}_{2} \mathrm{O}_{5}$ and $97.5 \mathrm{~kg} \mathrm{~K}_{2} \mathrm{O}^{-1}$ was applied. And for $200 \% \mathrm{RDF}, 300 \mathrm{~kg} \mathrm{~N}, 130 \mathrm{~kg} \mathrm{P}_{2} \mathrm{O}_{5}$ and $130 \mathrm{~kg} \mathrm{~K}_{2} \mathrm{O} \mathrm{ha}^{-1}$ was applied through urea, diammonium phosphate (DAP) and muriate of potash (MOP) respectively. $\mathrm{FeSO}_{4}$ and $\mathrm{ZnSO}_{4}$ were applied @ of $25 \mathrm{~kg} \mathrm{ha}^{-1}$. First intercultivation was done at 30 days after planting. Hand weeding was done at 30 and 55 days after planting to check the weed growth and to keep the plots free from weeds during the cropping period in all the dates of planting. With a spray of proclaim @ of $0.5 \mathrm{~g}$ litre-1, the crop was protected against fall army worm and stem borer. For all planting dates, the rainfall obtained during respective planting windows provided ample soil moisture for germination, emergence, and early establishment of seedlings. Rainfall fell during the crop growth cycle in the months of October $(323.2 \mathrm{~mm})$ and November $(21.0 \mathrm{~mm})$, and the rest of the season's crop was irrigated using the critical stage method. Since the experiment was conducted entirely under irrigated conditions, the crop did not experience moisture stress during the growing season.

\section{Growth parameters related to weather}

\section{Growing degree day (GDD)}

Growing days were determined in this study by simply adding up daily mean air temperatures above a given threshold or base temperature. It can be expressed mathematically as follows: 


$$
\operatorname{GDD}\left({ }^{\circ} \mathrm{C} \text { day }\right)=\frac{\mathrm{T}_{\text {max }}+\mathrm{T}_{\text {min }}}{2}-\mathrm{T}_{\mathrm{b}}
$$

Where,

$\mathrm{T}_{\max } \quad$ - Maximum temperature $\left({ }^{\circ} \mathrm{C}\right)$

$\mathrm{T}_{\min } \quad$ - Minimum temperature $\left({ }^{\circ} \mathrm{C}\right)$

$\mathrm{T}_{\mathrm{b}} \quad$ - Base temperature $10{ }^{\circ} \mathrm{C}\left(\right.$ Narcico et al. $\left.{ }^{13}\right)$

\section{Photothermal units (PTU)}

The photothermal units for a specific day represent the product of GDD and length of the day. Photo thermal units were calculated by using the equation given by Wilsie ${ }^{14}$.

\section{PTU $\left({ }^{\circ} \mathrm{C}\right.$ day hr $)=$ GDD X L}

Where, GDD - Growing degree days $\left({ }^{\circ} \mathrm{C}\right.$ day)

L - Day length (hrs)

\section{Heliothermal Units (HTU)}

The heliothermal units for a specific day are the product of multiplying GDD by the number of hours of bright sun that day. The tape in the Campbell-Stroke sunshine recorder burns when the strength of sunlight reaches a pre-determined threshold. The burn trace's total duration is equal to the amount of bright sunlight hours15. The formula was used to measure the total HTU for each phenophase's length

Accumulated HTU $\left({ }^{\circ} \mathrm{C}\right.$ day hr $)=$ GDD $\times$ Bright sunshine hours $($ hrs $)$

\section{Nutrient use efficiency}

The sum of product produced per unit of resource used is referred to as NUE. The amount of dry matter generated per unit of nutrient applied or absorbed is the mean nutrient efficiency. NUE is the difference between a genotype's yield on deficient soil and its yield at optimum nutrition ${ }^{16 .}$ Agronomic efficiency, 
physiological efficiency, and recover efficiency ${ }^{17}$ are the three types of nutrient efficiency.

The agronomic efficiency (AE) is defined as the economic production obtained per unit of nutrient applied. It can be calculated with the help of following equation.

$$
=\frac{\operatorname{AE}\left(\mathrm{kg} \mathrm{kg}^{-1}\right) \quad \begin{array}{l}
\text { Grain yield of fertilized crop }(\mathrm{kg})-\text { Grain yield unfertilized crop } \\
(\mathrm{kg})
\end{array}}{\text { Quantity of nutrient applied }(\mathrm{kg})}
$$

Sometimes, AE is also called as economic efficiency.

Physiological efficiency (PE) indicates grain yield increase in $\mathrm{kg}$ per $\mathrm{kg}$ nutrient uptake from fertilizer ${ }^{18}$. Expressed in kilogram per hectare $\left(\mathrm{kg} \mathrm{ha}^{-1}\right)$.

$$
\operatorname{PE}\left(\mathrm{kg} \mathrm{ha}^{-1}\right)=\frac{\text { Grain yield of F plot }- \text { Grain yield of A plot }}{\text { Nutrient uptake of the F plot }- \text { Nutrient uptake of the A plot }}
$$

Recovery efficiency (RE) is the quantity of nutrient taken up by the crop to the per unit of nutrient applied ${ }^{18}$ and expressed as percentage.

$$
\operatorname{RE}(\%)=\frac{\text { Nutrient uptake of the F plot }- \text { Nutrient uptake of the A plot }}{\text { Quantity of nutrient applied }} \times 100
$$

\section{Bio-economics}

The price in USD of the inputs prevailed at the time of their use was considered for working out the cost of cultivation per hectare treatment wise and expressed in USD ha ${ }^{-1}$. A gross return per hectare was calculated by taking into consideration of the price of the product that prevailed in market after harvest and grain yield per hectare and expressed in USD per hectare (USD ha ${ }^{-1}$ ). The net return per hectare was calculated treatment wise by subtracting the total cost of cultivation from gross return and expressed in USD per hectare (USD ha ${ }^{-1}$ ).

Net return $\left(\mathrm{USD} \mathrm{ha}^{-1}\right)=$ Gross return $\left(\mathrm{USD} \mathrm{ha}^{-1}\right)-$ Cost of cultivation $\left(\mathrm{USD} \mathrm{ha}^{-1}\right)$ 
The benefit cost ratio was calculated as follows.

$$
\text { Benefit cost ratio }(\mathrm{B}-\mathrm{C})=\frac{\text { Gross return }\left(\mathrm{USD} \mathrm{ha}^{-1}\right)}{\text { Cost of cultivation }\left(\mathrm{USD} \mathrm{ha}^{-1}\right)}
$$

Note- Indian rupee was converted using a 70 INR for 1 USD rate.

\section{Energetics}

All the agricultural inputs such as seeds, fertilizers, labour, animals, electricity, machinery, organic manures etc. and all the agricultural outputs such as grain and straw have their own equivalent energy (Mega Joules) values (Table 1). The energy balance was calculated using the data on input energy, output energy. From these, the net energy returns, energy use efficiency, energy productivity and specific energy were calculated using the following formulae ${ }^{19-23}$.

Net energy $\left(\mathrm{MJ} \mathrm{ha}^{-1}\right)=$ Total output energy $\left(\mathrm{MJ} \mathrm{ha}^{-1}\right)-$ Total input energy $\left(\mathrm{MJ}^{-} \mathrm{h}^{-}\right.$ $\left.{ }^{1}\right)$

$$
\text { Energy use efficiency }=\frac{\text { Total output energy }\left(\mathrm{MJ} \mathrm{ha}^{-1}\right)}{\text { Total input energy }\left(\mathrm{MJ} \mathrm{ha}^{-1}\right)}
$$

Energy productivity $\left(\mathrm{kg} \mathrm{MJ}^{-1}\right)=\frac{\text { Maize grain yield }\left(\mathrm{kg} \mathrm{ha}^{-1}\right)}{\text { Total input energy }\left(\mathrm{MJ} \mathrm{ha}^{-1}\right)}$

$$
\text { Specific energy }\left(\mathrm{MJ} \mathrm{kg}^{-1}\right)=\frac{\text { Total input energy }\left(\mathrm{MJ} \mathrm{ha}^{-1}\right)}{\text { Maize grain yield }\left(\mathrm{kg} \mathrm{ha}^{-1}\right)}
$$

\section{Statistical analysis and the interpretation of data}

Fisher's method of analysis of variance, as outlined by Gomez and Gomez36, was used to statistically analyse the data collected at various stages of crop development. The data was analysed with the MSTAT-C statistical programme, and the means were compared using the Duncan Multiple Range Test (DMRT) at a 5\% level of significance. The highest values were denoted by the letter ' $a$,' which was followed by 
the alphabets for lower values (b, c, d etc.). At the 0.05 level of significance, values denoted by the same small letter in the column do not vary significantly.

\section{Results}

\section{Weather, GDD, PTU, HTU and days for physiological maturity}

During the winter cropping season (2019-2020), a total rainfall of 352.0 $\mathrm{mm}$ was received out of which $323.2 \mathrm{~mm}$ was received during the planting month (October) (Fig.4). The highest and the lowest maximum temperature were $31.8^{\circ} \mathrm{C}$ (February) and $28.5^{\circ} \mathrm{C}$ (December), respectively, while the respective highest and the lowest minimum temperature were $15.5^{\circ} \mathrm{C}$ (January) and $20.3{ }^{\circ} \mathrm{C}$ (October) respectively were recorded during cropping period. The mean relative humidity ranged from 49.4 per cent in February to 79.8 per cent.

The accumulated GDD, PTU and HTU were significantly differed due to planting windows (Table 2). Planting during $1^{\text {st }}$ week of October recorded significantly higher GDD, PTU and HTU accumulation $\left(1530.1{ }^{0} \mathrm{C}\right.$ day, 17371.3 ${ }^{0} \mathrm{C}$ day hr and $11758.5{ }^{\circ} \mathrm{C}$ day hr respectively) and further it took significantly more number of days for physiological maturity (120.0 days). However, it was on par with planting during $2^{\text {nd }}$ week of October (116.1 days). Similarly among the fertility levels, $200 \%$ RDF recorded significantly higher accumulated GDD, PTU and HTU (1493.5 ${ }^{\circ} \mathrm{C}$ day, $17026.7{ }^{\circ} \mathrm{C}$ day $\mathrm{hr}$ and $12077.5{ }^{\circ} \mathrm{C}$ day hr respectively) and application of $200 \% \mathrm{RDF}$ took significantly more number of days for physiological maturity (118.0 days) and was on par with $150 \%$ RDF (1144.4 days).

Interaction effect of planting windows and fertility levels showed significant difference in GDD, PTU and HTU accumulation. Planting during $1^{\text {st }}$ week of October along with application of $200 \%$ RDF recorded higher GDD, PTU and HTU accumulation $\left(1591.1{ }^{0} \mathrm{C}\right.$ day, $17888.3{ }^{\circ} \mathrm{C}$ day $\mathrm{hr}$ and $12307.4{ }^{0} \mathrm{C}$ day hr respectively. Similarly, it recorded more number days for physiological maturity.

\section{Grain and biomass yield}


Planting during $1^{\text {st }}$ week of October recorded significantly higher grain yield and stover yield (8788 and $1220 \mathrm{~kg} \mathrm{ha}^{-1}$ respectively) and it was on par with planting during $2^{\text {nd }}$ week of October (8644 and $11980 \mathrm{~kg} \mathrm{ha}^{-1}$ respectively) (Table 3 and Fig.2).As planting delayed beyond $2^{\text {nd }}$ week of October, there was reduction in grain and stover yield significantly. The lowest grain and stover yield was recorded from crop sown during $1^{\text {st }}$ week of November. Grain and stover yield differed significantly due to fertility levels. Application of $200 \%$ RDF recorded significantly higher grain and stover yield (8320 and $11950 \mathrm{~kg} \mathrm{ha}^{-1}$ respectively) and it was on par with application of $150 \%$ RDF (8022 and $11410 \mathrm{~kg} \mathrm{ha}^{-1}$ respectively).

Interaction effect of planting windows and fertility levels showed significant difference in grain and stover yield. Planting during $1^{\text {st }}$ week of October along with application of $200 \%$ RDF recorded significantly higher grain and stover yield (9142 and $13050 \mathrm{~kg} \mathrm{ha}^{-1}$ respectively) and it was found on par with planting during $2^{\text {nd }}$ week of October along with application of $200 \%$ and $150 \%$ RDF, planting during $1^{\text {st }}$ week of October along with application of $150 \%$ RDF and $100 \%$ RDF. There is no significant difference in harvest index due to planting windows and fertility levels.

Nutrient use efficiency in winter maize (NUE) Agronomic efficiency of nitrogen $\left(\mathrm{AE}_{\mathrm{N}}\right)$, phosphorus $\left(\mathrm{AE}_{\mathrm{P}}\right)$ and potassium $\left(\mathrm{AE}_{\mathrm{K}}\right)$

$\mathrm{AE}_{\mathrm{N}}, \mathrm{AE}_{\mathrm{P}}$ and $\mathrm{AE}_{\mathrm{K}}$ were significantly higher with planting during $1^{\text {st }}$ week of October (22.80, 52.63 and $52.63 \mathrm{~kg} \mathrm{~kg}^{-1}$ respectively) and were on par with planting during $2^{\text {nd }}$ week of October $\left(21.80,48.72\right.$ and $48.72 \mathrm{~kg} \mathrm{~kg}^{-1}$ respectively) (Table 4). Significantly higher $\mathrm{AE}_{\mathrm{N}}, \mathrm{AE}_{\mathrm{P}}$ and $\mathrm{AE}_{\mathrm{K}}$ were recorded with application of $100 \% \operatorname{RDF}\left(23.41,53.93\right.$ and $53.93 \mathrm{~kg} \mathrm{~kg}^{-1}$ respectively).Interaction of planting windows and fertility levels recorded significant difference in $A E_{N}, A E_{P}$ and $A_{K}$. Planting during $1^{\text {st }}$ week of October along with application of $100 \%$ RDF recorded significantly higher $\mathrm{AE}_{\mathrm{N}}, \mathrm{AE}_{\mathrm{P}}$ and $\mathrm{AE}_{\mathrm{K}}\left(29.59,68.29\right.$ and $68.29 \mathrm{~kg} \mathrm{~kg}^{-1}$ respectively) and it was found on par with planting during $2^{\text {nd }}$ week of October along with application of $100 \%$ and planting during $3^{\text {rd }}$ week of October along with application of $100 \%$ RDF. 


\section{Physiological efficiency of nitrogen $\left(\mathrm{PE}_{\mathrm{N}}\right)$, phosphorus $\left(\mathrm{PE}_{\mathrm{P}}\right)$ and potassium $\left(\mathbf{P E}_{\mathbf{K}}\right)$}

$\mathrm{PE}_{\mathrm{N}}, \mathrm{PE}_{\mathrm{P}}$ and $\mathrm{PE}_{\mathrm{K}}$ were higher with planting during $1^{\text {st }}$ week of November (53.80, 209.01 and $69.58 \mathrm{~kg} \mathrm{ha}^{-1}$ respectively). Among fertility levels, higher $\mathrm{PE}_{\mathrm{N}}$, $\mathrm{PE}_{\mathrm{P}}$ and $\mathrm{PE}_{\mathrm{K}}$ were with application of $100 \% \mathrm{RDF}$ (50.67, 196.68 and $69.65 \mathrm{~kg} \mathrm{ha}^{-1}$ respectively). Interaction effect among planting windows and fertility levels showed significant difference with $\mathrm{PE}_{\mathrm{N}}$ and significantly higher $\mathrm{PE}_{\mathrm{N}}$ was recorded during $1^{\text {st }}$ week of November planting along with application of $100 \%$ RDF (59.50 $\left.\mathrm{kg} \mathrm{ha}^{-1}\right)$. Interaction effect found non-significant with respect to $\mathrm{PE}_{\mathrm{P}}$ and $\mathrm{PE}_{\mathrm{K}}$.

\section{Recovery efficiency of nitrogen $\left(R E_{N}\right)$, phosphorus $\left(R E_{P}\right)$ and potassium $\left(\mathbf{R E}_{\mathbf{K}}\right)$}

$\mathrm{PE}_{\mathrm{N}}, \mathrm{PE}_{\mathrm{P}}$ and $\mathrm{PE}_{\mathrm{K}}$ were significantly higher with planting during $1^{\text {st }}$ week of October (47.92, 29.32 and $78.99 \%$ respectively) and were on par with planting during $2^{\text {nd }}$ week of October $(44.36,27.70$ and $73.04 \%$ respectively). Among fertility levels, significantly higher $P E_{N}, P E_{P}$ and $P E_{K}$ were recorded with application of $100 \% \operatorname{RDF}(49.12,31.52$ and $81.23 \%$ respectively).

Treatment combinations of planting windows and fertility levels recorded significant difference in $\mathrm{RE}_{\mathrm{N}}, \mathrm{RE}_{\mathrm{P}}$ and $\mathrm{RE}_{\mathrm{K}}$. Planting during $1^{\text {st }}$ week of October along with application of $100 \% \mathrm{RDF}$ recorded significantly higher $\mathrm{RE}_{\mathrm{N}}, \mathrm{RE}_{\mathrm{P}}$ and $\mathrm{RE}_{\mathrm{K}}(62.19,38.43$ and $102.52 \%$ respectively) and it was found on par with planting during $2^{\text {nd }}$ week of October along with application of $100 \%$ and planting during $3^{\text {rd }}$ week of October along with application of $100 \%$ RDF.

\section{Energetics}

Energetics of winter maize significantly influenced by planting windows and fertility levels. The output energy, net energy, energy use efficiency and energy productivity were significantly higher from $1^{\text {st }}$ week of October planting (281233.7 MJ ha-1, 258121.4 $\mathrm{MJ} \mathrm{ha}^{-1}, 12.40$ and $0.39 \mathrm{~kg} \mathrm{MJ}^{-1}$ respectively) (Table 5). However, it was found on par with planting during $2^{\text {nd }}$ week of October (276831.5 $\mathrm{MJ} \mathrm{ha}^{-1}, 253719.2 \mathrm{MJ} \mathrm{ha}^{-1}, 12.19$ and $0.38 \mathrm{~kg} \mathrm{MJ}^{-1}$ respectively). Whereas, the 
specific energy was significantly higher in $1^{\text {st }}$ week of November planting (3.43 MJ $\left.\mathrm{kg}^{-1}\right)$.

Among fertility levels, significantly higher output energy, net energy and specific energy were recorded with application of $200 \%$ RDF (271692.2 $\mathrm{MJ} \mathrm{ha}^{-1}$, 244035.4 $\mathrm{MJ} \mathrm{ha}^{-1}$ and 3.36 $\mathrm{MJ} \mathrm{kg}^{-1}$ respectively). Whereas, The energy use efficiency and energy productivity were significantly higher with application of $100 \% \mathrm{RDF}$ (13.06 and $0.40 \mathrm{~kg} \mathrm{MJ}^{-1}$ respectively).Combination effect showed that the output energy and net energy were significantly higher in $1^{\text {st }}$ week of October planting along with $200 \% \operatorname{RDF}\left(297515.0 \mathrm{MJ} \mathrm{ha}^{-1}\right.$ and $269857.8 \mathrm{MJ} \mathrm{ha}^{-1}$ respectively). However, it was on par with planting during $2^{\text {nd }}$ week of October along with $200 \%$ RDF and planting during $1^{\text {st }}$ week of October along with $150 \%$ RDF. The energy use efficiency and energy productivity were significantly higher with planting during $1^{\text {st }}$ week of October along with application of $100 \%$ RDF (14.24 and $0.45 \mathrm{~kg} \mathrm{MJ}^{-1}$ respectively). However, it was on par with planting during $2^{\text {nd }}$ week of October along with $100 \% \mathrm{RDF}$ and planting during $3^{\text {rd }}$ week of October along with $100 \%$ RDF. The specific energy was significantly higher in $1^{\text {st }}$ week of November planting along with $200 \%$ RDF (3.85 MJ kg $\left.{ }^{-1}\right)$.

\section{Bio-economics}

Significantly higher gross return, net return and B-C ratio was recorded with planting during $1^{\text {st }}$ week of October (USD 2,331 ha- ${ }^{-1}$ USD 1,409 ha ${ }^{-1}$ and 2.53 respectively) and it was on par with planting during $2^{\text {nd }}$ week of October (USD 2,293 $\mathrm{ha}^{-1}$, USD 1,371 ha ${ }^{-1}$ and 2.49 respectively). Among fertility levels, significantly higher gross return, and net return were recorded with application of $200 \%$ RDF (USD 2,211 ha ${ }^{-1}$ and USD 1,231 ha ${ }^{-1}$ respectively). There was no significant effect observed with respect to B-C ratio among fertility levels (Table 6).Interaction effect showed that significantly higher gross return and net return were recorded with planting during $1^{\text {st }}$ week of October along with application $200 \%$ RDF (USD 2,429 ha ${ }^{-1}$ and USD 1,462 $\mathrm{ha}^{-1}$ respectively) and it was on par with planting during $2^{\text {nd }}$ week of October along with application $200 \% \mathrm{RDF}$ (USD 2,392 $\mathrm{ha}^{-1}$ and USD1,425 $\mathrm{ha}^{-1}$ respectively) and planting during $1^{\text {st }}$ week of October along with application $150 \%$ RDF (USD 2,338 $\mathrm{ha}^{-1}$ and USD 1,416 ha ${ }^{-1}$ respectively). Significantly higher B-C ratio was 
recorded with planting during $1^{\text {st }}$ week of October along with application $150 \%$ RDF.

\section{Discussion}

\section{Productivity of winter maize as influenced by planting windows}

The optimum date of planting is important for winter maize so that the genotype grown can complete its life cycle and express its full potential under optimum environmental conditions. For optimization of yield, planting at the appropriate time is very important as delayed planting can lead to a linear decrease in grain and stover yields ${ }^{37}$. Early planting in October significantly recorded higher productivity. Planting during October $1^{\text {st }}$ week recorded 1.65 , 8.04, 18.17 and 30.53 per cent linear increase in grain yield compared to planting during $2^{\text {nd }}, 3^{\text {rd }}, 4^{\text {th }}$ week of October and $1^{\text {st }}$ week of November respectively (Table 3 and Fig. 2). Higher grain yield obtained from October $1^{\text {st }}$ week planting was attributed to significant improvement in yield characters and dry matter accumulation (Fig.1a). Similar results were also obtained ${ }^{38}$. Late planting would lead to a lesser row number and less grain numbers in the rows of maize ${ }^{38}$. Further, increase in grain yield and yield attributes in first week of October planting was due to improved growth parameters viz., number of green leaves per plant, leaf area, leaf area index, total dry matter production (Fig. 1a), absolute growth rate (AGR) and crop growth rate (CGR) as a result of higher accumulation of growing degree days (GDD), photothermal units (PTU) and heliothermal units (HTU) compared to delayed planting (Table 2). Similar results were obtained by $\mathrm{Swetha}^{39}$ who reported that early planting of maize recorded higher grain yield compared to other delayed planting due to higher accumulation of GDD, PTU and HTU. Sutton and Stucker ${ }^{40}$ reported that delayed planting caused shortening of growing degree days (GDDs) accumulation during planting to physiological maturity.

There was optimum climatic condition (maximum mean temperature $27.9{ }^{\circ} \mathrm{C}$ and minimum mean temperature $19{ }^{\circ} \mathrm{C}$ in October month) prevailed for crop sown during first and second week of October (early) planting of winter maize; while, delayed planting recorded reduced growth in terms of leaf area and dry matter accumulation. Optimum temperature for maize germination is 21 
${ }^{\circ} \mathrm{C}$, for growth $32{ }^{\circ} \mathrm{C}$ and for tasselling $25-30{ }^{\circ} \mathrm{C}^{41}$. Late sown crop experienced average lower temperature than optimum $\left(18{ }^{\circ} \mathrm{C}\right.$ for germination, $23{ }^{\circ} \mathrm{C}$ for growth and $23{ }^{\circ} \mathrm{C}$ for tasseling). Further lesser availability of solar radiation (PTU) as a result of shorter day lengths in late planting condition leads shorter growing period (Table 2) which reduced the vegetative growth, dry matter accumulation (Fig. 1a) and finally the yield ${ }^{42,43}$. Environmental changes associated with different planting windows (sunshine and temperature) have a modifying effect on growth and development of maize plants ${ }^{41}$. In early planted maize, better photosynthesis was observed as evidenced by more leaf area index and accumulation of photosynthetes due to favourable climatic conditions ${ }^{45}$. Late planting brings horse weather parameters such as temperature, solar radiation, humidity during crop season which adversely affect the morphology, plant physiology and molecular level of plants ${ }^{46}$.

\section{Productivity of winter maize as influenced by fertility levels}

Application $200 \%$ RDF increased the grain yield by 3.71 and 10.98 per cent compared to $150 \%$ and $100 \%$ RDF respectively (Table 3 and Fig. $1 \mathrm{~b}$ ). The increased grain yield was due to improved yield attributes. Among several inputs essential for crop production, fertilizer management is of superlative importance. Further improved yield attributes was due to increased leaf area, leaf area index and total dry matter production (Fig. 1b). Steady increase AGR and CGR also play important role towards yield. Increased growth and yield parameters in $200 \%$ RDF were also due to higher available nutrients and their uptake $^{47}$. These results are conformity with the findings of Sreelatha et al. ${ }^{48}$. They reported higher yield and it's parameters in higher fertilizer levels (300:105:105 kg N- $\mathrm{P}_{2} \mathrm{O}_{5}-\mathrm{K}_{2} \mathrm{O} \mathrm{ha}^{-1}$ ) in southern India as plant could express its full genetic potential in higher fertility levels and better fertilizer levels reduced the cob barrenness percentage. The results are also in conformity with the findings of Damor et al. ${ }^{49}$ who reported higher yield and yield attributes of winter maize due to application of higher dose of inorganic fertilizer. There was a movement of photosynthates from source to sink and better physiological process. The results are also in close agreement with the findings of Mathukia et $a l .{ }^{50}$ who reported higher growth and yield attributes at higher nitrogen and phosphorus levels which was due to congenial nutritional environment for plant 
system on account of their greater availability from soil, which resulted in greater synthesis of amino acids, proteins and growth promoting substance, which enhanced the meristematic activity and increased the cell division and cell elongation. Further application of higher dose of fertilizer have increased interception, absorption and utilization of radiant energy which in turn increased photosynthesis and thereby plant height, stem girth and finally dry matter accumulation.

\section{Productivity of winter maize as influenced by planting windows and fertility levels}

Planting during $1^{\text {st }}$ week of October along with application of $200 \%$ $\mathrm{RDF}\left(\mathrm{W}_{1} \mathrm{~F}_{3}\right)$ recorded significantly higher grain and stover yield $\left(91.42 \mathrm{q} \mathrm{ha}^{-1}\right.$ and $130.5 \mathrm{q} \mathrm{ha}^{-1}$ respectively) and it was on par with planting during $2^{\text {nd }}$ week of October along with application of $200 \% \operatorname{RDF}\left(\mathrm{W}_{2} \mathrm{~F}_{3}\right)$ (Table 3 and Fig.1c). and planting during $1^{\text {st }}$ week of October along with application of $150 \%$ RDF $\left(\mathrm{W}_{1} \mathrm{~F}_{2}\right)$. The increased grain yield and stover yield was due to improved yield attributes. Increase in yield and yield attributes was due higher growth in terms of number of green leaves per plant, leaf area, leaf area index and total dry matter production (Fig. 1c) which increased AGR and CGR. These results are similar with findings of Verma et al. ${ }^{51}$ and they reported early planting and higher fertilizer levels favours good plant height, leaf area index and dry weight per plant due to favourable climatic conditions especially temperature which increased metabolic activities, increased assimilation and cell division within the plant. Increased growth attributes at $\mathrm{W}_{1} \mathrm{~F}_{3}$ was due to higher accumulation of GDD, PTU and HTU (Table 2). The increased application of nutrients increases the uptake of nutrients by plants in winter maize which might be due congenial nutrient environment in soil and availability higher nutrients in rhizospere ${ }^{49,52}$.

\section{Nutrients use efficiency (NUE) as influenced by planting windows}

Nutrients use efficiency (NUE) shows the ability of crops to take up and utilize nutrients for maximum yields. NUE depends on the plant's ability to take up nutrients efficiently from the soil, but also depends on internal transport, storage and remobilization of nutrients. NUE of applied fertilizers is very low 
due to many reasons like surface runoff, leaching, volatilization, denitrification and fixation in the soil. The increased yield levels show the higher nutrient use efficiency. The better planting date will provide the congenial environment to plants to uptake more nutrients so that productivity of crops is increased.

Significantly higher $\mathrm{AE}_{\mathrm{N}}, \mathrm{AE}_{\mathrm{P}}$ and $\mathrm{AE}_{\mathrm{K}}$ were recorded from crop sown during $1^{\text {st }}$ week of October and lower from crop sown during $1^{\text {st }}$ week of November (Table 4) due to higher grain yield in the first planting compared to yield from delayed planting. Similarly, higher $\mathrm{RE}_{\mathrm{N}}, \mathrm{RE}_{\mathrm{P}}$ and $\mathrm{RE}_{\mathrm{K}}$ were recorded from crop sown during $1^{\text {st }}$ week of October (Table 4) due to higher nutrient uptake. And lower recovery efficiency was obtained from crop sown during $1^{\text {st }}$ week of November on the contrary the highest PE was recorded when crop was sown during $1^{\text {st }}$ week of November for nitrogen, phosphorus and potassium and was on par with crop sown during $1^{\text {st }}$ week of October (Table 4). This indicates more capacity of plant to increase yield with per unit nutrient uptake. Similar results were reported by Srivastava et al. ${ }^{53}$ in maize crop and Sunita devi et al. ${ }^{54}$ in transplanted rice crop.

\section{Nutrient use efficiency (NUE) as influenced by fertility levels}

Significantly higher $\mathrm{AE}_{\mathrm{N}}, \mathrm{AE}_{\mathrm{P}}$ and $\mathrm{AE}_{\mathrm{K}}$ were recorded with application of $100 \% \mathrm{RDF}$ (Table 4). On the contrary lower agronomic efficiency for nutrients was recorded with higher fertility levels. For nitrogen, similar results were noticed by Vanlauwe et al. ${ }^{55}$ in maize based system and according to them higher agronomic efficiency was recorded in lower nitrogen level. The similar results were also obtained by Caviglia et al. ${ }^{56}$ who concluded higher agronomic efficiency in lower fertilizer level in both early and late sown maize. Similarly higher $\mathrm{PE}_{\mathrm{N}}, \mathrm{PE}_{\mathrm{P}}$ and $\mathrm{PE}_{\mathrm{K}}$ were recorded with application of $100 \% \mathrm{RDF}$ and lower physiological efficiency was recorded with higher fertility levels (Table 4). Similarly, the higher $R E_{N}, R E_{P}$ and $R E_{K}$ were obtained with application of $100 \% \mathrm{RDF}$, whereas lower recovery efficiency was observed in higher fertility levels (Table 4). Lesser the application of fertilizer higher will be the nutrient use efficiency ${ }^{57,58}$. This result is also conformity with the findings of Choudhary et $a l .^{59}$ and they concluded that yield increase was decreased with each increased level of nitrogen application. The highest agronomic nitrogen use 
efficiency was recorded with $60 \mathrm{~kg} \mathrm{~N} / \mathrm{ha}$. $\mathrm{N}$ level of $180 \mathrm{~kg} / \mathrm{ha}$ recorded the least. Yield increase due to per unit increase in uptake of $\mathrm{N}$ was decreased with increased levels of $\mathrm{N}$ application. The highest NUE always occurs at the lower parts of the yield response curve, where fertilizer inputs are the lowest. The effectiveness of fertilizers in increasing crop yields and optimizing farmer profitability should not be sacrificed for the sake of efficiency alone. There must be balance between optimum NUE and optimal crop productivity ${ }^{60}$.

Increased levels of fertilizer tend to lower the productive efficiency. Apparent recovery, which indicates the efficiency of absorption of applied nutrients, decreased at higher levels of fertilizer application. Each crop is having definite capacity to absorb a certain amount of nutrients, beyond which nutrients could not be taken up by the plants. When limited quantity of nutrients was applied, the crop can efficiently absorb the available nutrients in the soil solution and there by reduced the nutrient losses and increases the NUE ${ }^{61-64}$.

\section{Interaction effect of nutrient use efficiency (NUE) as influenced by fertility levels}

Interaction effect showed the higher agronomic efficiency with planting during $1^{\text {st }}$ week of October along with application of $100 \%$ RDF. The higher recovery efficiency for nitrogen, phosphorus and potassium was recorded with planting during $1^{\text {st }}$ week of October along with application of $100 \%$ RDF whereas, higher physiological efficiency was recorded with planting during $1^{\text {st }}$ week of November along with application of $100 \%$ RDF (Table 4). The higher agronomic efficiency in October $1^{\text {st }}$ week planting along with $100 \%$ RDF was due to higher grain yield in early planting and lower fertility level which increased the efficiency. The recovery efficiency was also higher in October $1^{\text {st }}$ week planting which was due to higher applied nutrient uptake. The higher physiological efficiency was recorded during $1^{\text {st }}$ week of November which might be due to more capacity of plant to increase yield with per unit nutrient uptake. Lesser the application of fertilizer, higher will be the nutrient use efficiency ${ }^{53,58,65-68}$.

\section{Energetics as influenced by planting windows}


In agriculture development, the energy audit of various resources plays a key role in resource management. Under the changing global climatic conditions and increasingly growing energy demands necessitate the development of a production system which utilizes less energy and produces more energy as output. The energetics was calculated per hectare and then these input data were multiplied with conversion factor of its energy equivalent. The energy indices were determined by using standard equation ${ }^{30}$.

The total input energy was lower for early planting windows due to lower irrigation requirement ${ }^{71}$. The productivity of the crop sown on $1^{\text {st }}$ and $2^{\text {nd }}$ week of October were higher than delayed sown crop which resulted in higher output energy and lower output energy was recorded with crop sown during $1^{\text {st }}$ week of November. The net energy was also higher from early sown winter maize because of higher output energy during these planting windows and lower net energy was recorded with crop sown during $1^{\text {st }}$ week of November. Further, energy use efficiency was highest with crop sown during $1^{\text {st }}$ week of October and was found on par with planting during $2^{\text {nd }}$ week of October and lowest energy use efficiency was recorded in last planting during $1^{\text {st }}$ week of November (Fig 3a). The higher energy use efficiency in early sown crop compared to late planting was due to higher grain yield and output of energy. Energy productivity was also higher from crop sown during $1^{\text {st }}$ week of October and was on par with planting during $2^{\text {nd }}$ week of October. Lower energy productivity was observed in $1^{\text {st }}$ week of November planting (Fig. 3a). Higher energy productivity was directly correlated with higher productivity. The specific energy was higher in $1^{\text {st }}$ week of November planting and lower specific energy was recorded in $1^{\text {st }}$ week of October planting (Fig. 3a). The higher specific energy in delayed planting was due to higher energy requirement to produce unit yield. The same results were observed by Puniya et al. ${ }^{72}$. The energy use efficiency (EUE) was significantly positively correlated with net energy return, energy productivity, energy intensity, energy output, helio-thermal use efficiency, heat use efficiency and significant negatively correlated with specific energy and helio-thermal units $^{71,72}$.

\section{Energetics as influenced by fertility levels}


According to many researchers the inputs such as fuel, electricity, machinery, seed, fertilizer and chemical take significant share of the energy supplies to the production system in modern agriculture. Foremost important among them is careful management of fertilizers, because on the one hand, in many cases it alone share more than 50 per cent of total input energy used in a system and the other, it is the most imperative growth factor for proper growth and development of plants ${ }^{11}$. It was observed that, the fertilizers had the highest rate of energy equivalency of all the inputs used in maize production at 51.5 per cent $^{12}$.

The total energy input in $200 \%$ RDF was higher than other fertility levels due higher rate of application. Aakash et al. ${ }^{9}$ reported that fertilizer management is very essential since it utilized almost $70 \%$ of total input energy used in maize production. Application of $200 \%$ RDF recorded higher total output energy. Lower total output of energy was recorded with application of $100 \%$ RDF due lower grain yield. Significantly higher grain and stover yield in higher fertility levels increased the total output energy. Hence, the net energy was higher in $200 \%$ RDF and lower net energy was recorded with application of $100 \%$ RDF. While, the energy use efficiency and energy productivity were higher in $100 \%$ RDF (Fig. 3b). The higher energy use efficiency was due to higher ratio of output to input energy. Similarly, higher energy productivity was due to higher ratio of yield to input energy. The specific energy was higher with application $200 \%$ RDF (Fig. 3b). This was due to higher energy requirement to produce unit yield in $200 \% \mathrm{RDF}^{73-76}$. The findings of Khokhar et al. ${ }^{63}$ are similar to above results and they concluded higher input energy, output energy and energy balance in higher fertility levels and higher energy use efficiency and energy productivity in lower fertility levels in both maize and wheat crop. Singh et al. ${ }^{60}$ reported similar results and they reported higher output energy and net energy return in site specific nutrient management compared to farmer practice and RDF due to higher yield levels in precision nutrient management practices. Choudhary et al. ${ }^{59}$, Biswasi et al. ${ }^{77}$, Jayadeva and Prabhakar shetty ${ }^{78}$ also found that higher input energy, output energy and net energy in higher fertility levels compared to lower fertility levels. 


\section{Interaction effect of planting windows and fertility levels on energetics}

Interaction of planting windows and fertility levels plays an important role in energy flow in winter maize. Relatively higher input energy was recorded in $1^{\text {st }}$ week of November planting along with $200 \%$ RDF. Planting during $1^{\text {st }}$ week of October along with application $200 \%$ RDF $\left(\mathrm{W}_{1} \mathrm{~F}_{3}\right)($ Fig.3c) recorded higher total output energy compared to other treatment combinations. The higher output energy was due to higher yield levels in $\mathrm{W}_{1} \mathrm{~F}_{3}$. Higher net energy was recorded with planting during $1^{\text {st }}$ week of October along with application of $200 \% \mathrm{RDF}$ and it was found on par with early planting during $2^{\text {nd }}$ week of October and $1^{\text {st }}$ week of October along with application of either $200 \%$ RDF or $150 \%$ RDF. This was because there was higher input energy use which increased the grain and stover yield resulting in increased the total output energy and net energy, whereas higher energy use efficiency was recorded with planting during $1^{\text {st }}$ week of October along with application of $100 \%$ RDF and was found on par with planting during $2^{\text {nd }}$ week of October along with application of $100 \% \mathrm{RDF}$, planting during $3^{\text {rd }}$ week of October along with application of $100 \%$ RDF (Fig. 3c). This was because the higher ratio of output to input energy. Similarly higher energy productivity was recorded with planting during $1^{\text {st }}$ week of October along with application of $100 \%$ RDF and it was on par with planting during $2^{\text {nd }}$ week of October along with application of $100 \%$ RDF, planting during $3^{\text {rd }}$ week of October along with application of 100 $\%$ RDF (Fig. 3c). Higher energy productivity was due to higher ratio of grain yield to energy input. Higher specific energy was recorded with planting during $1^{\text {st }}$ week of November along with application of $200 \%$ RDF and was found on par with planting during $4^{\text {th }}$ week of October along with application of $200 \%$ RDF (Fig. 3c). This was because in this treatment combination there was a higher requirement of energy to produce unit yield ${ }^{72,73,79}$.

\section{Bio-economics}

Significantly higher gross return, net return and B-C ratio was recorded with planting during $1^{\text {st }}$ week of October and it was on par with planting during $2^{\text {nd }}$ week of October. The higher gross return and net return were due to higher grain yield and stover yield in these two planting windows, whereas 
significantly lower gross return, net return and B-C ratio recorded with planting at $1^{\text {st }}$ week of November was due to lower productivity ${ }^{46}$. Among the fertility levels, significantly higher gross return and net return was recorded with application of $200 \% \mathrm{RDF}$ and was on par with application of $150 \%$ RDF due to higher grain and stover yield in these two fertility levels, whereas significantly lower gross return and net return was recorded with application of $100 \%$ RDF due to its lower grain and stover yield. There is no significant difference with respect to $\mathrm{B}-\mathrm{C}$ ratio ${ }^{69}$.

Interaction effect showed that significantly higher gross return and net return were recorded with planting during $1^{\text {st }}$ week of October along with application of $200 \% \mathrm{RDF}$ and was on par with planting during $2^{\text {nd }}$ week of October with $200 \%$ RDF and planting during $1^{\text {st }}$ week of October with $150 \%$ The higher gross return and net return in these interactions were due to higher grain and stover yield, whereas significantly lower gross return and net return were recorded with planting during $1^{\text {st }}$ week of November along with application of $100 \%$ RDF was due to its lower productivity of crop $^{70}$.

\section{Conclusion}

Planting of maize in winter season is more suitable than rainy season by looking at crop growth and productivity. The best planting windows to obtain higher productivity, NUE, energy use efficiency, energy productivity, net return and $\mathrm{B}-\mathrm{C}$ ratio were $1^{\text {st }}$ and $2^{\text {nd }}$ week October. Among fertility levels, application of $200 \%$ and $150 \%$ RDF showed higher productivity. Whereas, higher NUE, energy use efficiency and energy productivity was recorded with $100 \%$ RDF. Considering all these variables, it could be inferred that planting maize during $1^{\text {st }}$ or $2^{\text {nd }}$ week October along with application $150 \%$ RDF is most productive, remunerative and energy efficient in south India.

\section{References}

1. USDA. Foreign agricultural service. World agricultural production. Circular series WAP 8-20. Online: https://apps.fas.usda.gov/psdonline/circulars/production.pdf (2020). 
2. IndiaAgristat. Area, production, and average yield, Directorate of Economics and Statistics, Department of Agriculture and Cooperation report, New Delhi. http://www.indiaagristat.com/ (2020).

3. Singh, N. et al. Rabi Maize Opportunities Challenges, Directorate of Maize Research, Pusa Campus, New Delhi -110 012, Technical Bulletin, No. 9: 32 p (2012).

4. IndiaAgristat. Area, production, and average yield, Directorate of Economics and Statistics, Department of Agriculture and Cooperation report, New Delhi. http://www.indiaagristat.com/ (2019).

5. Anapalli, S. S., Ma, L., Nielsen, D. C., Vigil, M. F. and Ahuja, L. R. Simulating planting date effects on corn production using RZWQM and CERES-Maize models. Agron. J., 17(97): 58-71 (2005).

6. Babannavar, P. B. Response of sunflower (Helianthus annus L.) to the varying levels of nitrogen and phosphorus under saline water irrigation. M. Sc. (Agri.) Thesis, Univ. Agril. Sci. Dharwad, Karnataka, India (1990).

7. Sheperd, L. N., HSicks, D. R., and Schmidth, W.H. Maximizing the advantages of early corn planting. National Corn Handbook, Crop Management. Purdue University Cooperative Extension Service. West Lafayette, Indiana. NCH-35 (1991).

8. Barut, Z. B., Ertekin, C., Karaagac, H. A. Tillage effects on energy use for corn silage in Mediterranean Coastal of Turkey. Energy 36, 5466-5475 (2011).

9. Aakash, Bhayal, L., Thakur, N. S., Kirar, S. K. and Choudhary, S. K. Energetics of maize production system as influenced by varieties and nitrogen scheduling. J. Exp. Biol. Agric. Sci., 7(5): 462-467 (2019).

10. Aghaalikhani, M., Kazemi-Poshtmasari, H., Habibzadeh, F. Energy usepattern in rice production: a case study from Mazandaran province, Iran. Energy Convers. Manag., 69: 157-162 (2013).

11. Pannell, D. J. Economic perspectives on nitrogen in farming systems: managing tradeoffs between production, risk and the environment. Soil Research 55: 473-478 (2016).

12. Vural Hasan, Efecan Ibrahim. An analysis of energy use and input costs for maize production in Turkey. J. Food Agriculture Environ., 10(2): 613-616 (2012).

13. Narcico, G., Ragini, P. and Venturi, A. Agro meteorological aspects of crops in Italy, Spain and Greece: a summary review of durum wheat, barley, maize, rice, sugarbeet, sunflower, soybean, rapeseed, potato, tobacco, cotton, olive and grape, Publication EUR 14124 EN of the Office for Official Publications of the European Communities; Series Agriculture, Luxembourg (1992). 
14. Wilsie, C. P. Crop Adoption and Distribution. Freeman W. H. and Co., London, 5559 (1962).

15. Rajput, R. P. Respone of Soybean crop to climatic and soil environments. Ph. $D$. Thesis, IARI, New Delhi, India (1980).

16. Graham, R. D. Nutrient efficiency objective in cereal breading pp, 165-170. In: A. R. Fergnson, R. L, Bieloski and I. B. Ferguson (Eds), Proc. $8^{\text {th }}$ International coll. Plant anal Frt, Prob, Auckland (1978).

17. Crasswell, E. T. and Godwin, D. C. The efficiency of nitrogen fertilizer applied to cereals in different climates. Adv. Nutrit., 1: 1-15 (1984).

18. Fagaria, N. K., Baligar, V. C. and Jones, C. A. Growth and mineral nutrition of field crops. CRC press, pp. 57-67 (2011).

19. Mittal, V. K., Mittal, J. P. and Dhavan, K. C. Research project on energy requirements in agriculture sector coordinating cell, Agricultural Engineering, PAU, Ludhiana. pp.62 (1985).

20. Gopalan, C., Sastri, B. V. R. and Balasubramaniam, S. C. Nutritive Value of Indian Foods. National Institute of Nutrition, ICMR, Hyderabad (1978).

21. Binning, A. S., Pathak, B. S. and Panesar The energy audit of crop production system research report. School of energy studies for agriculture, Panjab Agricultural University, Ludhiana, Panjab, India (1983).

22. Singh, J. M. On farm energy use pattern in different cropping systems in Haryana, India. M.Sc. Thesis, International Institute of Management University of Flensburg, Germany (2002).

23. Subbian, P., Annadurai, K. and Palaniappon, S. P. Agriculture-Facts and Figures. Kalyani Publishers, New Delhi, p.135 (2006).

24. Barut, Z.B., Ertekin, C., Karaagac, H.A. Tillage effects on energy use for corn silage in Mediterranean Coastal of Turkey. Energy 36, 5466-5475 (2011).

25. Kumar, V. et al. Effect of different tillage and seeding methods on energy use efficiency and productivity of wheat in the Indo-Gangetic Plains. Field Crop Res., 142: $1-8$ (2013).

26. Shahin, S., Jafari, A., Mobli, H., Rafiee, S., Karini, M. Effect of farm size on energy ratio on wheat production: a case study from Arbadil province of Iran. Am. Eurasian J. Agric. Environ. Sci., 3: 604-608 (2008). 
27. Yadav, S.N., Chandra, R., Khura, T.K., Chuhan, N.S. Energy input-output analysis and mechanization status for cultivate on of rice and maize crops in Sikkim. Agric. Eng. Int. CIGR J. 15: 108-116 (2013).

28. Devi, S., Hooda, V. S. and Singh, J. Energy input-output analysis for production of wheat under different planting techniques and herbicide treatments. Int. J. Curr. Microbiol. App. Sci., 7: 749-760 (2018).

29. Singh, H., Mishra, D. and Nahar, N. M. Energy use pattern in production agriculture of a typical village in arid zone India-Part I. Energy Conversion Management 43: 2275-2286 (2002).

30. Avval Mousavi, Rafiee, S. H., Jafari, S. A. and Mohammadi, Energy storage in field operations of maize production using data envelopment analysis approach. Int $J$. Energy Environ, 2(5): 933-944 (2011).

31. Nassiri, S.M., Singh, S. Non-parametric energy use efficiency: energy ratio and specific energy for irrigated wheat crop production. Iran Agric. Res., 27: 30-38 (2009).

32. Rahman, S., Rahman, S. Energy productivity and efficiency of maize accounting for the choice of growing season and environmental factors: an empirical analysis from Bangladesh. Energy, 49: 339-346 (2013).

33. Shahan, S., Jafari, A., Mobli, H., Rafiee, S., Karimi, M. Energy use and economical analysis of wheat production in Iran, a case study from Ardabil province. J. Agric. Technol. 4: 77-88 (2008).

34. Devasenapathy, P., Senthilkumar, G., Shanmugam, P. M. Energy management in crop production. Indian J. Agron. 54(1): 80-90 (2009).

35. Zahedi, M., Mondani, F. and Eshghizadeh, H. R. Analyzing the energy balances of double-cropped cereals in an arid region. Energy report 1: 43-49 (2015).

36. Gomez, K. A. and Gomez, A. A. Statistical Procedure for Agriculture Research, $2^{\text {nd }}$ Ed., John Willey and Sons, New York, p. 68 (1984).

37. Anapalli, S. S., Ma, L., Nielsen, D. C., Vigil, M. F. and Ahuja, L. R. Simulating planting date effects on corn production using RZWQM and CERES-Maize models. Agron. J., 17(97): 58-71 (2005).

38. Khan, Z. H. et al. Phenology and yield of sweet corn land races influenced by planting dates. Sarhad J. Agric., 25(2): 153-157 (2009). 
39. Swetha Sree, M. Phenological response of maize (Zea mays L.) to photoperiod and temperature. M. Sc. (Agri.) Thesis. Acharya N.G. Ranga Agric. Univ., Tirupati, India (2017).

40. Sutton, L. M., and Stucker, R. E. Growing degree days to black layer compared to relative maturity rating of corn hybrids. Crop Science, 14: 408-412 (1974).

41. Panda, S. C. Maize crop science. Agrobios publishers, Jodhpur, India (2010).

42. Biswas, M., Rahman, A.H. M. M. and Ahmed, F. Effect of variety and planting geometry on the growth and yield of hybrid maize. J. Agric. Environ. Sci., 3(2): 1732 (2014).

43. Sangoi, L., and Salvador, R. J. Influence of plant height and leaf number on maize production at high plant densities. Pesquira Agropecuaria Brasileira. Brasilia, 33: 297-306 (1998).

44. Dekhane, S. S. And Dumbre, R. B. Influence of different sowing dates on plant growth and yield of hybrid sweet corn. Adv. Res. J. Crop Improv. 8(2): 191-194 (2017).

45. Keerthi, P., Prabhakar Reddy, G. and Sunitha, N. Effect of sowing time on growth and yield of sweet corn cultivars. Int. J. Curr. Microbiol. App. Sci., 6(4): 777-782 (2017).

46. Singh, G., Kumar, S., Singh, R. And Singh, S. Growth, yield of baby corn (Zea mays L.) as influenced by varieties, spacings and date of sowing. Indian. J. Agric. Res., 49(4): 353-357 (2015).

47. Nand, V. Effect of spacing and fertility levels on protein content and yield of hybrid and composite maize (Zea mays L.) grown in rabi season. J. Agric. Veterinary. Sci., 8(9): 26-31 (2015).

48. Sreelatha, D., Laxmi, Y. S., Anuradha, M. and Reddy, R. Interactive effect of plant population and fertility levels on the productivity of maize under Rice- Maize system. Proceeding International Maize conference (2012).

49. Damor, N., Patel, G. N., Patel, C. K. and Vagela, S. Response of Rabi maize (Zea mays L.) to different dates of sowing and fertility levels. Int. J. Sci. Environ. Tech., 6(3): 1905-1911 (2017).

50. Mathukia, R. K., Choudhary, R. P., Shivran, A. and Bhosale, N. Response of rabi sweet corn to plant geometry and fertilizer. Current Biotica., 7(4): 294-298 (2014). 
51. Verma, N. K., Pandey, B. K., Singh, U. P. and Lodhi, M. D. Effect of sowing dates in relation to integrated nitrogen management on growth, yield and quality of rabi maize (Zea mays L.). The J. Animal. Plant. Sci., 22(2): 324-329 (2012).

52. Jaswinder, K., Himani, K., Pankaj, S. and Neeraj, J. Effect of plant densities and integrated nutrient management on productivity, nutrient uptake and quality of sweet corn (Zea mays L. Saccharata). J. Agric. Veterinary. Sci., 12(5): 38-42 (2019).

53. Srivastava, R. K., Panda, R. K., Chakraborty, A. and Halder, D. Enhancing grain yield, biomass and nitrogen use efficiency of maize by varying sowing dates and nitrogen rate under rainfed and irrigated conditions. Field Crops Res., xxx (2017).

54. Sunita Devi et al. Nutrient uptake, use efficiency and yield of rice as influenced by time of transplanting and nitrogen levels. Oryza, 56(2): 209-213 (2019).

55. Vanlauwe, B. et al. Agronomic use efficiency of $\mathrm{N}$ fertilizer in maize-based systems in sub-Saharan Africa within the context of integrated soil fertility management. Plant Soil, 339: 35-50 (2011).

56. Caviglia, O. P., Melchiori, R. J. M. and Sadras, V. O. Nitrogen utilization efficiency in maize as affected by hybrid and $\mathrm{N}$ rate in late-sown crops. Field Crops Res., 168: 27-37 (2014).

57. Nasser, Kh. B. G. Effect of nitrogen rate and plant density on agronomic nitrogen efficiency and maize yields following wheat and faba bean. Am-Euras. J. Agric. \& Environ. Sci., 5(3): 378-386 (2009).

58. Vishwanatha, V. E. Integrated nutrient management in popcorn (Zea mays var. Everta). M. Sc. (Agri.) Thesis. Univ. Agric. Sci., Dharwad, India (2019).

59. Choudhary, R. L. et al. Energetics and nitrogen-use efficiency of kharif maize in conservation agriculture-based maize (Zea mays)-wheat (Triticum aestivum) sequence. Int. J. Chem. Stud., 8(2): 1252-1258 (2020).

60. Singh, C. S., Akansha Raj, Singh, A. K., Singh, A. K. and Singh, S. K. Nutrient expert assisted site-specific-nutrient-management: An alternative precision fertilization technology for maize production in Chota-nagpur plateau region of Jharkhand. J. Pharmacogn. Phytochem., SP1: 760-764 (2018).

61. Amanullah, M. M. et al. Influence of fertilizer levels and growth regulating substances on growth, nutrient use efficiency and yield of hybrid maize. Madaras Agric. J., 97(1-3): 68-72 (2010). 
62. Kaizzi, K. C. et al. Maize response to fertilizer and nitrogen use efficiency in Uganda. Agron. J., 104: 73-82 (2012).

63. Khokhar, A. K. et al. Tillage and nutrient-management practices for improving productivity and soil physico-chemical properties in maize (Zea mays)-wheat (Triticum aestivum) cropping system under rainfed conditions in Kandi region of Punjab. Indian J. Agron., 63(3): 278-284 (2018).

64. Onwonga, R. N., Lelei, J. J. and Macharia, J. K. Comparative Effects of Soil Amendments on Phosphorus Use and Agronomic Efficiencies of Two Maize Hybrids in Acidic Soils of Molo County, Kenya. Am. J. Exp. Agric., 3(4): 939-958 (2013).

65. Devi, S., Hooda, V. S. and Singh, J. Energy input-output analysis for production of wheat under different planting techniques and herbicide treatments. Int. J. Curr. Microbiol. App. Sci., 7: 749-760 (2018).

66. Dutta, R. and Enghipi, J. Effect of dates of sowing and nitrogen levels on nutrient uptake (kg/ha), nutrient use efficiency, and quality of Yellow Sarson (Brassica rapa var. trilocularis) grown in rice fallow. J. Oilseed Brassica, 7(2): 174-179 (2016).

67. Kumar, V. et al. Nutrient uptake and fertilizer-use efficiency of maize hybrids under conservation agriculture with nutrient expert based SSNM practices. Ann. Agric. Res. New series, 36(2): 160-166 (2015).

68. Mishra, V. K. Water expense and nutrient use efficiency of wheat and winter maize as influenced by integrated nutrient management. Agropedology, 10:1-5 (2000).

69. Jyothi, K. J. Nutrient management for higher productivity of rabi maize in north coastal zone of A. P. M. Sc. (Agri.) Thesis, Acharya N. G. Ranga Agri. University., Rajendra nagar, Hyderabad, India (2013).

70. Singh, S. K., Singh, R. N., Ram, U. S. and Singh, M. K. Growth, yield attributes, yield and economics of winter popcorn (Zea mays everta Sturt.) as influenced by planting time, fertility level and plant population under late sown condition. J. App. Natural. Sci., 8(3): 1438-1443 (2016).

71. Ravisankar, N. et al. Evaluation of time, method of sowing and varieties for tablepurpose groundnut (Arachis hypogaea) under Island ecosystem. Indian J. Agril. Sci., 80(4): 293-297 (2010).

72. Puniya, R. et al. Influence of sowing dates and varieties on the yield, heat use efficiency, energy utilization and economics of summer mungbean. Legume Res., 3789: 1-7 (2017). 
73. Charate, S. Response of little millet (Panicum sumatrense) to levels of nitrogen and potassium. M. Sc. (Agri.) Thesis, University of Agricultural Sciences, Bengaluru, Karnataka (2017).

74. Kumar, B. and Karmakar, S. Effect of tillage and nutrient management on fodder yield, economics and energetics of oat (Avena sativa L.). Forage Res., 41(1): 19-22 (2015).

75. Kumar, A. et al. Effect of nutrient-and moisture-management practices on crop productivity, water-use efficiency and energy dynamics in rainfed maize (Zea mays) +soybean (Glycine max) intercropping system. Indian J. Agron., 60(1): 152-156 (2015).

76. Kumar, R. and Kumar, M. Effect of fertility levels and seed rates on productivity, profitability and energetics of linseed (Linum usitatissimum L.) Under foot hill condition of Nagaland. Int, J. Agricult. Stat. Sci., 11(1): 275-280 (2015).

77. Biswasi, S. K., Barik, A. K. and Bastia, D. K. Productivity, economics and energetics of hybrid maize (zea mays 1.) In odisha as influenced by integrated nutrient management. Int. J. Bio-res. Env. Agril. Sci., 3(4): 619-623 (2017).

78. Jaydeva, H. M. and Prabhakara shetty. Influence of crop establishment techniques and sources of nutrients on productivity, energetics and economics of rice. Oryza 45(2): 166-168 (2008).

79. Raghavendra, M. Potassium management studies under conservation agriculture based maize (Zea mays L.) - wheat (Triticum aestivum L.) cropping system. Ph. D. Thesis. Indian Agricultural Research Institute, New Delhi, India (2016). 
Table 1. Energy equivalents (MJ unit ${ }^{-1}$ ) used for energy input and output calculations.

\begin{tabular}{|c|c|c|c|}
\hline Particulars & Unit & $\begin{array}{c}\text { Energy } \\
\text { equivalent } \\
\left(\mathrm{MJ} \mathrm{ha}^{-1}\right)\end{array}$ & References \\
\hline \multicolumn{4}{|l|}{ I. Inputs } \\
\hline \multicolumn{4}{|l|}{ 1. Human labour } \\
\hline Adult man & $\mathrm{hr}$ & 1.96 & $\begin{array}{l}\text { Barut et al. }{ }^{24} \text {, Kumar et } a l_{.}{ }^{25} \text {, Shahin et } \\
\text { al. }^{26} \text {, Yadav et } a l^{27}\end{array}$ \\
\hline Adult women & $\mathrm{hr}$ & 1.57 & Devi et $a .^{28}$ \\
\hline 2. Bullocks & Pair-hr & 10.1 & 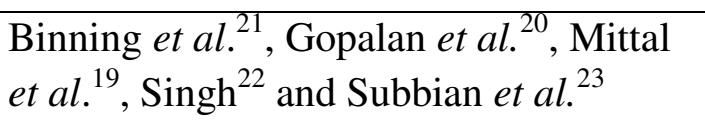 \\
\hline \multicolumn{4}{|c|}{ 3. Fuel and machinery } \\
\hline Diesel & $1 \mathrm{~L}$ & 56.31 & $\begin{array}{l}\text { Barut et al. }{ }^{24} \text {, Kumar et al. }{ }^{25} \text {, Shahin et } \\
\text { al. }^{26}, \text { Singh } \text { et } \text { al. }^{29} \text {, Yadav et al. }{ }^{27}\end{array}$ \\
\hline Tractor & $\mathrm{hr}$ & 62.7 & Singh et al. ${ }^{29}$ \\
\hline \multicolumn{4}{|c|}{ 4. Manures and fertilizers } \\
\hline Farm Yard Manure & $1 \mathrm{t}$ & 303.1 & Avval Mousavi et al..$^{30}$ \\
\hline Nitrogen & $\mathrm{kg}$ & 60.6 & Singh et $a l^{29}$ \\
\hline Phosphorus & $\mathrm{kg}$ & 11.1 & Singh et al. ${ }^{29}$ \\
\hline Potassium & $\mathrm{kg}$ & 6.7 & Singh et al. ${ }^{29}$ \\
\hline
\end{tabular}




\begin{tabular}{|c|c|c|c|}
\hline Zinc sulphate & $\mathrm{kg}$ & 20.9 & Nassiri and Singh $^{31}$ \\
\hline 5. Maize seeds & $\mathrm{kg}$ & 15.2 & Rahman and Rahman ${ }^{32}$, Yadav et al. ${ }^{27}$ \\
\hline 6. Insecticide & $\mathrm{kg}$ & 120 & $\begin{array}{l}\text { Kumar et al. }{ }^{25} \text {, Shahin } \text { et } a l^{26}{ }^{26} \text {, Shahan et } \\
\text { al. }\end{array}$ \\
\hline 7. Irrigation water & $\mathrm{M}^{3}$ & 1.02 & Devasenapathy et al. $^{34}$ \\
\hline \multicolumn{4}{|l|}{ II. Outputs } \\
\hline Maize grains & $\mathrm{kg}$ & 14.7 & 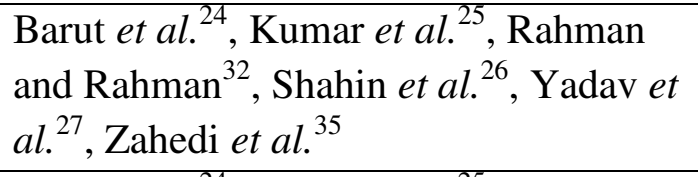 \\
\hline Maize stover & $\mathrm{kg}$ & 12.5 & 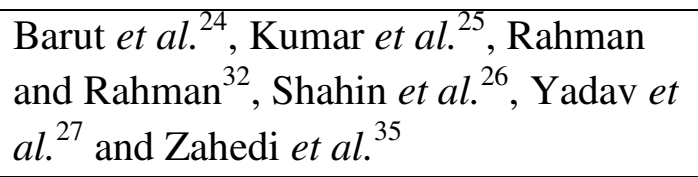 \\
\hline
\end{tabular}


Table 2: Days to physiological maturity, growing degree days, photo thermal units and heliothermal units of winter maize as influenced by sowing windows and fertility levels

\begin{tabular}{|c|c|c|c|c|}
\hline Treatment & $\begin{array}{l}\text { Days to } \\
\text { physiological } \\
\text { maturity }\end{array}$ & $\begin{array}{l}\text { Growing } \\
\text { degree } \\
\text { days ( }{ }^{0} \mathrm{C} \\
\text { day) }\end{array}$ & $\begin{array}{l}\text { Photo } \\
\text { thermal } \\
\text { units }\left(^{0} \mathrm{C}\right. \\
\text { day hr) }\end{array}$ & $\begin{array}{l}\text { Heliotherm } \\
\text { al units ( } \\
\text { C day hr) }\end{array}$ \\
\hline \multicolumn{5}{|l|}{ Factor I: Sowing windows } \\
\hline $\mathrm{W}_{1}: 1^{\text {st }}$ week of October & $120.0^{\mathrm{a}}$ & $1530.1^{\mathrm{a}}$ & $17371.3^{\mathrm{a}}$ & $11758.5^{\mathrm{a}}$ \\
\hline $\mathrm{W}_{2}: 2^{\text {nd }}$ week of October & $116.1^{\mathrm{ab}}$ & $1493.4^{\mathrm{a}}$ & $16578.0^{\mathrm{b}}$ & $11655.0^{\mathrm{b}}$ \\
\hline $\mathrm{W}_{3}: 3^{\text {rd }}$ week of October & $114.2^{\mathrm{ab}}$ & $1466.9^{b}$ & $16268.3^{\mathrm{c}}$ & $11597.4^{\mathrm{c}}$ \\
\hline $\mathrm{W}_{4}: 4^{\text {th }}$ week of October & $112.0^{\mathrm{bc}}$ & $1444.9^{c}$ & $15966.6^{\mathrm{d}}$ & $11381.6^{\mathrm{d}}$ \\
\hline $\mathrm{W}_{5}: 1^{\text {st }}$ week of November & $108.9^{\mathrm{c}}$ & $1242.4^{\mathrm{d}}$ & $15416.5^{\mathrm{e}}$ & $11274.0^{\mathrm{e}}$ \\
\hline S.Em \pm & 1.26 & 2.53 & 19.33 & 12.83 \\
\hline \multicolumn{5}{|l|}{ Factor II: Fertility levels } \\
\hline $\mathrm{F}_{1}: 100 \% \mathrm{RDF}$ & $110.5^{\mathrm{b}}$ & $1392.7^{\mathrm{c}}$ & $15602.8^{c}$ & $11149.0^{\mathrm{c}}$ \\
\hline $\mathrm{F}_{2}: 150 \% \mathrm{RDF}$ & $114.4^{\mathrm{a}}$ & $1421.0^{\mathrm{b}}$ & $16330.9^{\mathrm{b}}$ & $11373.3^{\mathrm{b}}$ \\
\hline $\mathrm{F}_{3}: 200 \% \mathrm{RDF}$ & $118.0^{\mathrm{a}}$ & $1493.5^{\mathrm{a}}$ & $17026.7^{\mathrm{a}}$ & $12077.5^{\mathrm{a}}$ \\
\hline S.Em \pm & 1.63 & 3.27 & 24.95 & 16.56 \\
\hline \multicolumn{5}{|l|}{ Interaction $(\mathbf{W} \times \mathbf{F})$} \\
\hline $\mathrm{W}_{1} \mathrm{~F}_{1}: 1^{\text {st }}$ week of Oct $+100 \% \mathrm{RDF}$ & $116.7^{\mathrm{a}-\mathrm{d}}$ & $1471.4^{\mathrm{e}}$ & $16838.2^{\mathrm{d}}$ & $11409.2^{\mathrm{f}}$ \\
\hline $\mathrm{W}_{1} \mathrm{~F}_{2}: 1^{\mathrm{st}}$ week of Oct $+150 \% \mathrm{RDF}$ & $120.5^{\mathrm{ab}}$ & $1527.8^{\mathrm{c}}$ & $17387.3^{\mathrm{b}}$ & $11558.9^{\mathrm{e}}$ \\
\hline $\mathrm{W}_{1} \mathrm{~F}_{3}: 1^{\text {st }}$ week of Oct $+200 \% \mathrm{RDF}$ & $122.9^{\mathrm{a}}$ & $1591.1^{\mathrm{a}}$ & $17888.3^{\mathrm{a}}$ & $12307.4^{\mathrm{a}}$ \\
\hline $\mathrm{W}_{2} \mathrm{~F}_{1}: 2^{\text {nd }}$ week of Oct $+100 \% \mathrm{RDF}$ & $111.8^{\mathrm{b}-\mathrm{e}}$ & $1444.4^{\mathrm{f}}$ & $15849.2^{\mathrm{g}}$ & $11156.4^{\mathrm{g}}$ \\
\hline $\mathrm{W}_{2} \mathrm{~F}_{2}: 2^{\text {nd }}$ week of Oct $+150 \% \mathrm{RDF}$ & $116.3^{\mathrm{a}-\mathrm{d}}$ & $1474.4^{\mathrm{e}}$ & $16550.3^{\mathrm{e}}$ & $11652.6^{\mathrm{d}}$ \\
\hline $\mathrm{W}_{2} \mathrm{~F}_{3}: 2^{\text {nd }}$ week of Oct $+200 \% \mathrm{RDF}$ & $120.2^{\mathrm{ab}}$ & $1561.3^{\mathrm{b}}$ & $17334.6^{\mathrm{b}}$ & $12155.9^{\mathrm{b}}$ \\
\hline $\mathrm{W}_{3} \mathrm{~F}_{1}: 3^{\text {rd }}$ week of Oct $+100 \% \mathrm{RDF}$ & $110.4^{\mathrm{c}-\mathrm{e}}$ & $1433.4^{\mathrm{f}}$ & $15594.6^{\mathrm{h}}$ & $11351.9^{\mathrm{f}}$ \\
\hline $\mathrm{W}_{3} \mathrm{~F}_{2}: 3^{\text {rd }}$ week of Oct $+150 \% \mathrm{RDF}$ & $114.2^{\mathrm{a}-\mathrm{e}}$ & $1445.0^{\mathrm{f}}$ & $16193.0^{f}$ & $11365.4^{\mathrm{f}}$ \\
\hline $\mathrm{W}_{3} \mathrm{~F}_{3}: 3^{\text {rd }}$ week of Oct $+200 \% \mathrm{RDF}$ & $118.2^{\mathrm{a}-\mathrm{c}}$ & $1522.4^{\mathrm{c}}$ & $17017.2^{\mathrm{c}}$ & $12074.7^{\mathrm{b}}$ \\
\hline $\mathrm{W}_{4} \mathrm{~F}_{1}: 4^{\text {th }}$ week of Oct $+100 \% \mathrm{RDF}$ & $108.2^{\mathrm{de}}$ & $1397.8^{\mathrm{g}}$ & $15175.1^{\mathrm{i}}$ & $11012.7^{\mathrm{h}}$ \\
\hline $\mathrm{W}_{4} \mathrm{~F}_{2}: 4^{\text {th }}$ week of Oct $+150 \% \mathrm{RDF}$ & $112.0^{\mathrm{b}-\mathrm{e}}$ & $1440.0^{f}$ & $15928.3^{\mathrm{g}}$ & $11170.6^{\mathrm{g}}$ \\
\hline $\mathrm{W}_{4} \mathrm{~F}_{3}: 4^{\text {th }}$ week of Oct $+200 \% \mathrm{RDF}$ & $116.5^{\mathrm{a}-\mathrm{d}}$ & $1497.0^{\mathrm{d}}$ & $16796.5^{\mathrm{d}}$ & $11961.3^{\mathrm{c}}$ \\
\hline $\mathrm{W}_{5} \mathrm{~F}_{1}: 1^{\mathrm{st}}$ week of Nov $+100 \% \mathrm{RDF}$ & $105.3^{\mathrm{e}}$ & $1213.9^{\mathrm{i}}$ & $14556.9^{j}$ & $10814.6^{\mathrm{i}}$ \\
\hline $\mathrm{W}_{5} \mathrm{~F}_{2}: 1^{\text {st }}$ week of Nov $+150 \% \mathrm{RDF}$ & $109.2^{\mathrm{c}-\mathrm{e}}$ & $1218.0^{\mathrm{i}}$ & $15595.6^{\mathrm{h}}$ & $11119.0^{\mathrm{g}}$ \\
\hline $\mathrm{W}_{5} \mathrm{~F}_{3}: 1^{\text {st }}$ week of Nov $+200 \% \mathrm{RDF}$ & $112.3^{\mathrm{b}-\mathrm{e}}$ & $1295.5^{\mathrm{h}}$ & $16097.0^{\mathrm{f}}$ & $11888.3^{c}$ \\
\hline S.Em \pm & 2.82 & 6.67 & 43.21 & 28.6 \\
\hline
\end{tabular}


Table 3: Grain yield, stover yield and harvest index of winter maize as influenced by sowing windows and fertility levels

\begin{tabular}{|c|c|c|c|}
\hline Treatment & $\begin{array}{l}\text { Grain yield } \\
\left(\mathrm{kg} \mathrm{ha}^{-1}\right)\end{array}$ & $\begin{array}{l}\text { Stover yield } \\
\left(\mathrm{kg} \mathrm{ha}^{-1}\right)\end{array}$ & $\begin{array}{l}\text { Harvest } \\
\text { index }(\%)\end{array}$ \\
\hline \multicolumn{4}{|l|}{ Factor I: Sowing windows } \\
\hline $\mathrm{W}_{1}: 1^{\text {st }}$ week of October & $8787^{\mathrm{a}}$ & $12200^{\mathrm{a}}$ & $41.99^{\mathrm{a}}$ \\
\hline $\mathrm{W}_{2}: 2^{\text {nd }}$ week of October & $8644^{\mathrm{ab}}$ & $11980^{\mathrm{ab}}$ & $41.86^{\mathrm{a}}$ \\
\hline $\mathrm{W}_{3}: 3^{\text {rd }}$ week of October & $8133^{\mathrm{b}}$ & $11320^{\mathrm{bc}}$ & $41.83^{\mathrm{a}}$ \\
\hline $\mathrm{W}_{4}: 4^{\text {th }}$ week of October & $7436^{\mathrm{c}}$ & $10750^{\mathrm{cd}}$ & $41.03^{\mathrm{a}}$ \\
\hline $\mathrm{W}_{5}: 1^{\text {st }}$ week of November & $6732^{\mathrm{d}}$ & $10330^{\mathrm{d}}$ & $39.54^{\mathrm{a}}$ \\
\hline S.Em \pm & 154.4 & 209.5 & 0.62 \\
\hline \multicolumn{4}{|l|}{ Factor II: Fertility levels } \\
\hline $\mathrm{F}_{1}: 100 \% \mathrm{RDF}$ & $7497^{\mathrm{b}}$ & $10590^{b}$ & $41.34^{\mathrm{a}}$ \\
\hline $\mathrm{F}_{2}: 150 \% \mathrm{RDF}$ & $8022^{\mathrm{a}}$ & $11410^{\mathrm{a}}$ & $41.34^{\mathrm{a}}$ \\
\hline $\mathrm{F}_{3}: 200 \% \mathrm{RDF}$ & $8320^{\mathrm{a}}$ & $11950^{\mathrm{a}}$ & $41.06^{\mathrm{a}}$ \\
\hline S.Em \pm & 199.3 & 269.2 & 0.80 \\
\hline \multicolumn{4}{|l|}{ Interaction $(\mathbf{W} \times \mathbf{F})$} \\
\hline $\mathrm{W}_{1} \mathrm{~F}_{1}: 1^{\text {st }}$ week of Oct $+100 \% \mathrm{RDF}$ & $8403^{\mathrm{a}-\mathrm{c}}$ & $11280^{\mathrm{b}-\mathrm{g}}$ & $42.86^{\mathrm{a}}$ \\
\hline $\mathrm{W}_{1} \mathrm{~F}_{2}: 1^{\text {st }}$ week of Oct $+150 \% \mathrm{RDF}$ & $8814^{\mathrm{ab}}$ & $12270^{\mathrm{a}-\mathrm{c}}$ & $41.83^{\mathrm{a}}$ \\
\hline $\mathrm{W}_{1} \mathrm{~F}_{3}: 1^{\text {st }}$ week of Oct $+200 \% \mathrm{RDF}$ & $9142^{\mathrm{a}}$ & $13050^{\mathrm{a}}$ & $41.26^{\mathrm{a}}$ \\
\hline $\mathrm{W}_{2} \mathrm{~F}_{1}: 2^{\text {nd }}$ week of Oct $+100 \% \mathrm{RDF}$ & $8141^{a-d}$ & $11000^{\mathrm{c}-\mathrm{g}}$ & $42.23^{\mathrm{a}}$ \\
\hline $\mathrm{W}_{2} \mathrm{~F}_{2}: 2^{\text {nd }}$ week of Oct $+150 \%$ RDF & $8783^{\mathrm{ab}}$ & $12170^{\mathrm{a}-\mathrm{d}}$ & $41.93^{\mathrm{a}}$ \\
\hline $\mathrm{W}_{2} \mathrm{~F}_{3}: 2^{\text {nd }}$ week of Oct $+200 \% \mathrm{RDF}$ & $9007^{\mathrm{ab}}$ & $12780^{\mathrm{ab}}$ & $41.40^{\mathrm{a}}$ \\
\hline $\mathrm{W}_{3} \mathrm{~F}_{1}: 3^{\text {rd }}$ week of Oct $+100 \% \mathrm{RDF}$ & $78.9^{\mathrm{b}-\mathrm{e}}$ & $10690^{\mathrm{d}-\mathrm{g}}$ & $42.33^{\mathrm{a}}$ \\
\hline $\mathrm{W}_{3} \mathrm{~F}_{2}: 3^{\text {rd }}$ week of Oct $+150 \% \mathrm{RDF}$ & $8217^{\mathrm{a}-\mathrm{d}}$ & $11480^{b-f}$ & $41.76^{\mathrm{a}}$ \\
\hline $\mathrm{W}_{3} \mathrm{~F}_{3}: 3^{\text {rd }}$ week of Oct $+200 \% \mathrm{RDF}$ & $8321^{\mathrm{a}-\mathrm{c}}$ & $11800^{\mathrm{a}-\mathrm{e}}$ & $41.40^{\mathrm{a}}$ \\
\hline $\mathrm{W}_{4} \mathrm{~F}_{1}: 4^{\text {th }}$ week of Oct $+100 \% \mathrm{RDF}$ & $6913^{\text {ef }}$ & $1019^{\mathrm{f} 0 \mathrm{~g}}$ & $40.53^{\mathrm{a}}$ \\
\hline $\mathrm{W}_{4} \mathrm{~F}_{2}: 4^{\text {th }}$ week of Oct $+150 \% \mathrm{RDF}$ & $7444^{\mathrm{c}-\mathrm{e}}$ & $10780^{\mathrm{c}-\mathrm{g}}$ & $41.23^{\mathrm{a}}$ \\
\hline $\mathrm{W}_{4} \mathrm{~F}_{3}: 4^{\text {th }}$ week of Oct $+200 \% \mathrm{RDF}$ & $7948^{\mathrm{b}-\mathrm{e}}$ & $11290^{\mathrm{b}-\mathrm{g}}$ & $41.33^{\mathrm{a}}$ \\
\hline $\mathrm{W}_{5} \mathrm{~F}_{1}: 1^{\text {st }}$ week of Nov $+100 \% \mathrm{RDF}$ & $6164^{\mathrm{f}}$ & $9780^{\mathrm{g}}$ & $38.76^{\mathrm{a}}$ \\
\hline $\mathrm{W}_{5} \mathrm{~F}_{2}: 1^{\text {st }}$ week of Nov $+150 \% \mathrm{RDF}$ & $6850^{\text {ef }}$ & $10380^{\mathrm{e}-\mathrm{g}}$ & $39.96^{\mathrm{a}}$ \\
\hline $\mathrm{W}_{5} \mathrm{~F}_{3}: 1^{\text {st }}$ week of Nov $+200 \% \mathrm{RDF}$ & $7180^{\mathrm{d}-\mathrm{f}}$ & $10840^{\mathrm{c}-\mathrm{g}}$ & $39.9^{\mathrm{a}}$ \\
\hline S.Em \pm & 345.0 & 466.1 & 1.37 \\
\hline
\end{tabular}

Highest values were denoted with 'a' followed by the next alphabets for lower values $(b, c, d$ etc.). Value denoted by same small letter in the column does not differ significantly at 0.05 level of significance. 
Table 4: Nutrient use efficiency of nitrogen, phosphorus and potassium as influenced by sowing windows and fertility levels

\begin{tabular}{|c|c|c|c|c|c|c|c|c|c|}
\hline Treatment & $\mathrm{AE}_{\mathrm{N}}\left(\mathrm{kg} \mathrm{kg}^{-1}\right)$ & $A E_{P}\left(\mathrm{~kg} \mathrm{~kg}^{-1}\right)$ & $\mathrm{AE}_{\mathrm{K}}\left(\mathrm{kg} \mathrm{kg}^{-1}\right)$ & $\mathrm{PE}_{\mathrm{N}}\left(\mathrm{kg} \mathrm{ha}^{-1}\right)$ & $\operatorname{PE}_{\mathrm{P}}\left(\mathrm{kg} \mathrm{ha}^{-1}\right)$ & $\mathbf{P E}_{\mathrm{K}}\left(\mathrm{kg} \mathrm{ha}^{-1}\right)$ & $\mathbf{R E}_{\mathrm{N}}(\%)$ & $\operatorname{RE}_{\mathbf{P}}(\%)$ & $\mathrm{RE}_{\mathrm{K}}(\%)$ \\
\hline \multicolumn{10}{|l|}{ Factor I: Sowing windows } \\
\hline $\mathrm{W}_{1}: 1^{\text {st }}$ week of October & $22.80^{\mathrm{a}}$ & $52.63^{\mathrm{a}}$ & $52.63^{\mathrm{a}}$ & $49.01^{\mathrm{ab}}$ & $184.24^{\mathrm{a}}$ & $68.57^{\mathrm{a}}$ & $47.92^{\mathrm{a}}$ & $29.32^{\mathrm{a}}$ & $78.99^{\mathrm{a}}$ \\
\hline $\mathrm{W}_{2}: 2^{\text {nd }}$ week of October & $21.80^{\mathrm{a}}$ & $48.72^{\mathrm{ab}}$ & $48.72^{\mathrm{ab}}$ & $47.94^{\mathrm{b}}$ & $181.72^{\mathrm{a}}$ & $68.65^{\mathrm{a}}$ & $44.36^{\mathrm{a}}$ & $27.70^{\mathrm{a}}$ & $73.04^{\mathrm{ab}}$ \\
\hline $\mathrm{W}_{3}: 3^{\text {rd }}$ week of October & $19.80^{\mathrm{a}}$ & $45.69^{b}$ & $45.69^{b}$ & $48.37^{\mathrm{b}}$ & $184.45^{\mathrm{a}}$ & $66.42^{\mathrm{a}}$ & $41.59^{\mathrm{a}}$ & $26.19^{\mathrm{a}}$ & $69.09^{\mathrm{b}}$ \\
\hline $\mathrm{W}_{4}: 4^{\text {th }}$ week of October & $16.14^{\mathrm{b}}$ & $37.25^{\mathrm{c}}$ & $37.25^{\mathrm{c}}$ & $48.74^{\mathrm{ab}}$ & $194.31^{\mathrm{a}}$ & $69.50^{\mathrm{a}}$ & $33.92^{\mathrm{b}}$ & $21.97^{b}$ & $56.01^{\mathrm{c}}$ \\
\hline $\mathrm{W}_{5}: 1^{\text {st }}$ week of November & $12.74^{\mathrm{c}}$ & $29.40^{\mathrm{d}}$ & $29.40^{\mathrm{d}}$ & $53.80^{\mathrm{a}}$ & $209.01^{\mathrm{a}}$ & $69.58^{\mathrm{a}}$ & $26.78^{\mathrm{c}}$ & $18.04^{\mathrm{c}}$ & $44.04^{\mathrm{d}}$ \\
\hline S.Em \pm & \begin{tabular}{|l|}
0.75 \\
\end{tabular} & 1.74 & 1.74 & \begin{tabular}{|l|}
1.31 \\
\end{tabular} & 17.76 & 4.28 & 1.70 & \begin{tabular}{|l|}
0.81 \\
\end{tabular} & 1.98 \\
\hline $\mathrm{F}_{1}: 100 \% \mathrm{RDF}$ & $23.41^{\mathrm{a}}$ & $53.93^{\mathrm{a}}$ & $53.93^{\mathrm{a}}$ & $50.67^{\mathrm{a}}$ & $196.68^{\mathrm{a}}$ & $69.65^{\mathrm{a}}$ & $49.12^{\mathrm{a}}$ & $31.52^{\mathrm{a}}$ & $81.23^{\mathrm{a}}$ \\
\hline $\mathrm{F}_{2}: 150 \% \mathrm{RDF}$ & $18.03^{b}$ & $41.06^{\mathrm{b}}$ & $41.06^{\mathrm{b}}$ & $49.73^{\mathrm{a}}$ & $187.26^{\mathrm{a}}$ & $68.28^{\mathrm{a}}$ & $37.39^{b}$ & $23.48^{\mathrm{b}}$ & $61.65^{b}$ \\
\hline $\mathrm{F}_{3}: 200 \% \mathrm{RDF}$ & $14.51^{\mathrm{c}}$ & $33.19^{\mathrm{c}}$ & $33.19^{\mathrm{c}}$ & $48.32^{\mathrm{a}}$ & $188.29^{\mathrm{a}}$ & $67.69^{\mathrm{a}}$ & $30.23^{\mathrm{c}}$ & $18.91^{\mathrm{c}}$ & $49.82^{\mathrm{c}}$ \\
\hline S.Em \pm & 0.97 & 2.25 & 2.25 & \begin{tabular}{|l|l|}
1.69 \\
\end{tabular} & 22.93 & 5.53 & 2.20 & 1.04 & 2.56 \\
\hline \multicolumn{10}{|l|}{ Interaction $(\mathbf{W} \times \mathbf{F})$} \\
\hline $\mathrm{W}_{1} \mathrm{~F}_{1}: 1^{\text {st }}$ week of Oct $+100 \%$ RDF & $29.59^{\mathrm{a}}$ & $68.29^{\mathrm{a}}$ & $68.29^{\mathrm{a}}$ & $47.54^{\mathrm{b}}$ & $185.96^{\mathrm{a}}$ & $66.47^{\mathrm{a}}$ & $62.19^{\mathrm{a}}$ & $38.43^{\mathrm{a}}$ & $102.52^{\mathrm{a}}$ \\
\hline $\mathrm{W}_{1} \mathrm{~F}_{2}: 1^{\text {st }}$ week of Oct $+150 \% \mathrm{RDF}$ & $21.55^{\mathrm{bc}}$ & $49.74^{\mathrm{bc}}$ & $49.74^{\mathrm{bc}}$ & $49.54^{b}$ & $185.99^{\mathrm{a}}$ & $72.13^{\mathrm{a}}$ & $45.29^{\mathrm{bc}}$ & $27.28^{b}$ & $74.66^{\mathrm{b}}$ \\
\hline $\mathrm{W}_{1} \mathrm{~F}_{3}: 1^{\text {st }}$ week of Oct $+200 \% \mathrm{RDF}$ & $17.26^{\mathrm{c}-\mathrm{f}}$ & $39.83^{\mathrm{c}-\mathrm{f}}$ & $39.83^{\mathrm{c}-\mathrm{f}}$ & $49.95^{\mathrm{b}}$ & $180.76^{\mathrm{a}}$ & $67.10^{\mathrm{a}}$ & $36.27^{\mathrm{c}-\mathrm{f}}$ & $22.22^{\mathrm{b}-\mathrm{e}}$ & $59.79^{\mathrm{c}-\mathrm{e}}$ \\
\hline $\mathrm{W}_{2} \mathrm{~F}_{1}: 2^{\text {nd }}$ week of Oct $+100 \%$ RDF & $27.17^{\mathrm{a}}$ & $62.20^{\mathrm{a}}$ & $62.20^{\mathrm{a}}$ & $47.55^{b}$ & $174.68^{\mathrm{a}}$ & $70.35^{\mathrm{a}}$ & $56.64^{\mathrm{ab}}$ & $35.73^{\mathrm{a}}$ & $93.13^{\mathrm{a}}$ \\
\hline $\mathrm{W}_{2} \mathrm{~F}_{3}: 2^{\text {nd }}$ week of Oct $+200 \% \mathrm{RDF}$ & $16.81^{\mathrm{c}-\mathrm{f}}$ & $37.25^{\mathrm{c}-\mathrm{g}}$ & $37.25^{\mathrm{c}-\mathrm{g}}$ & $47.61^{\mathrm{b}}$ & $185.48^{\mathrm{a}}$ & $68.63^{\mathrm{a}}$ & $33.92^{\mathrm{c}-\mathrm{g}}$ & $20.93^{\mathrm{c}-\mathrm{e}}$ & $55.92^{\mathrm{c}-\mathrm{f}}$ \\
\hline $\mathrm{W}_{3} \mathrm{~F}_{1}: 3^{\text {rd }}$ week of Oct $+100 \%$ RDF & $25.96^{\mathrm{ab}}$ & $59.92^{\mathrm{ab}}$ & $59.92^{\mathrm{ab}}$ & $49.71^{\mathrm{b}}$ & $190.37^{\mathrm{a}}$ & $65.86^{\mathrm{a}}$ & $54.57^{\mathrm{ab}}$ & $34.58^{\mathrm{a}}$ & $91.49^{\mathrm{a}}$ \\
\hline $\mathrm{W}_{3} \mathrm{~F}_{2}: 3^{\text {rd }}$ week of Oct $+150 \%$ RDF & $18.90^{\mathrm{ce-}}$ & $43.62^{\mathrm{c}-\mathrm{e}}$ & $43.62^{\mathrm{c}-\mathrm{e}}$ & $47.89^{b}$ & $176.39^{\mathrm{a}}$ & $66.52^{\mathrm{a}}$ & $39.67^{c-e}$ & $24.89^{\mathrm{b}-\mathrm{d}}$ & $65.47^{\mathrm{b}-\mathrm{d}}$ \\
\hline $\mathrm{W}_{3} \mathrm{~F}_{3}: 3^{\text {rd }}$ week of Oct $+200 \% \mathrm{RDF}$ & $14.52^{\mathrm{d}-\mathrm{g}}$ & $33.51^{\mathrm{e}-\mathrm{g}}$ & $33.51^{\mathrm{e}-\mathrm{g}}$ & $47.51^{b}$ & $186.58^{\mathrm{a}}$ & $66.88^{\mathrm{a}}$ & $30.52^{\mathrm{d}-\mathrm{g}}$ & $19.09^{\mathrm{d-f}}$ & $50.30^{\mathrm{e}-\mathrm{g}}$ \\
\hline $\mathrm{W}_{4} \mathrm{~F}_{1}: 4^{\text {th }}$ week of Oct $+100 \%$ RDF & $19.67^{\mathrm{cd}}$ & $45.41^{\mathrm{c}-\mathrm{e}}$ & $45.41^{\mathrm{c}-\mathrm{e}}$ & $49.04^{b}$ & $166.28^{\mathrm{a}}$ & $72.02^{\mathrm{a}}$ & $41.35^{\mathrm{cd}}$ & $27.33^{b}$ & $68.18^{\mathrm{bc}}$ \\
\hline $\mathrm{W}_{4} \mathrm{~F}_{2}: 4^{\text {th }}$ week of Oct $+150 \%$ RDF & $15.46^{\mathrm{d}-\mathrm{g}}$ & $35.69^{\mathrm{d}-\mathrm{g}}$ & $35.69^{\mathrm{d}-\mathrm{g}}$ & $49.33^{b}$ & $215.34^{\mathrm{a}}$ & $69.45^{\mathrm{a}}$ & $32.50^{\mathrm{d}-\mathrm{g}}$ & $20.92^{\mathrm{c}-\mathrm{e}}$ & $53.57^{\mathrm{d}-\mathrm{f}}$ \\
\hline $\mathrm{W}_{4} \mathrm{~F}_{3}: 4^{\text {th }}$ week of Oct $+200 \%$ RDF & $13.28^{\mathrm{e}-\mathrm{g}}$ & $30.64^{\mathrm{fg}}$ & $30.64^{\mathrm{fg}}$ & $47.83^{b}$ & $201.29^{\mathrm{a}}$ & $67.01^{\mathrm{a}}$ & $27.90^{\mathrm{e}-\mathrm{g}}$ & $17.63^{\mathrm{ef}}$ & $46.27^{\mathrm{e}-\mathrm{g}}$ \\
\hline $\mathrm{W}_{5} \mathrm{~F}_{1}: 1^{\text {st }}$ week of Nov $+100 \%$ RDF & $14.66^{\mathrm{d}-\mathrm{g}}$ & $33.85^{\mathrm{d}-\mathrm{g}}$ & $33.85^{\mathrm{d}-\mathrm{g}}$ & $59.50^{\mathrm{a}}$ & $266.11^{\mathrm{a}}$ & $73.57^{\mathrm{a}}$ & $30.84^{\mathrm{d}-\mathrm{g}}$ & $21.54^{\mathrm{b}-\mathrm{e}}$ & $50.84^{\mathrm{e}-\mathrm{g}}$ \\
\hline $\mathrm{W}_{5} \mathrm{~F}_{2}: 1^{\text {st }}$ week of Nov $+150 \%$ RDF & $12.87^{\mathrm{fg}}$ & $29.60^{\mathrm{fg}}$ & $29.60^{\mathrm{fg}}$ & $53.22^{\mathrm{ab}}$ & $173.58^{\mathrm{a}}$ & $66.32^{\mathrm{a}}$ & $26.96^{\mathrm{fg}}$ & $17.88^{\mathrm{ef}}$ & $44.45^{\mathrm{fg}}$ \\
\hline $\mathrm{W}_{5} \mathrm{~F}_{3}: 1^{\text {st }}$ week of Nov $+200 \%$ RDF & $10.72^{g}$ & $24.73^{\mathrm{g}}$ & $24.73^{\mathrm{g}}$ & $48.68^{\mathrm{b}}$ & $187.33^{\mathrm{a}}$ & $68.84^{\mathrm{a}}$ & $22.53^{\mathrm{g}}$ & $14.68^{\mathrm{f}}$ & $36.82^{\mathrm{g}}$ \\
\hline S.Em \pm & 1.68 & 3.89 & 3.89 & 2.92 & 39.71 & 9.57 & 3.80 & 1.80 & 4.43 \\
\hline
\end{tabular}


Table 5: Energetics of winter maize as influenced by sowing windows and fertility levels

\begin{tabular}{|c|c|c|c|c|c|c|}
\hline Treatment & \begin{tabular}{|l} 
Input \\
energy \\
$\left(\mathbf{M J ~ h a}^{-1}\right)$
\end{tabular} & $\begin{array}{l}\text { Output } \\
\text { energy } \\
\left(\mathrm{MJ} \mathrm{ha}^{-1}\right)\end{array}$ & $\begin{array}{l}\text { Net energy } \\
\left(\mathrm{MJ} \mathrm{ha}^{-1}\right)\end{array}$ & $\begin{array}{l}\text { Energy } \\
\text { use } \\
\text { efficiency }\end{array}$ & $\begin{array}{l}\text { Energy } \\
\text { productivity } \\
\left(\mathrm{kg} \mathrm{MJ}^{-1}\right)\end{array}$ & $\begin{array}{l}\text { Specific } \\
\text { yenergy } \\
\left(\mathrm{MJ} \mathrm{kg}^{-1}\right)\end{array}$ \\
\hline \multicolumn{7}{|l|}{ Factor I: Sowing windows } \\
\hline $\mathrm{W}_{1}: 1^{\text {st }}$ week of October & 23141.7 & $281233.7^{\mathrm{a}}$ & $258121.4^{\mathrm{a}}$ & $12.40^{\mathrm{a}}$ & $0.39^{\mathrm{a}}$ & $2.62^{\mathrm{c}}$ \\
\hline $\mathrm{W}_{2}: 2^{\text {nd }}$ week of October & 23141.7 & $276831.5^{\mathrm{a}}$ & $253719.2^{\mathrm{a}}$ & $12.19^{\mathrm{ab}}$ & $0.38^{\mathrm{ab}}$ & $2.65^{\mathrm{c}}$ \\
\hline $\mathrm{W}_{3}: 3^{\text {rd }}$ week of October & 23147.6 & $260631.8^{\mathrm{b}}$ & $237519.5^{\mathrm{b}}$ & $11.72^{\mathrm{b}}$ & $0.36^{\mathrm{b}}$ & $2.85^{\mathrm{c}}$ \\
\hline $\mathrm{W}_{4}: 4^{\text {th }}$ week of October & 23153.5 & $243285.6^{\mathrm{c}}$ & $220173.3^{c}$ & $10.72^{\mathrm{c}}$ & $0.33^{\mathrm{c}}$ & $3.12^{\mathrm{b}}$ \\
\hline $\mathrm{W}_{5}: 1^{\text {st }}$ week of November & 23153.5 & $227703.2^{\mathrm{d}}$ & $204085.9^{\mathrm{d}}$ & $10.03^{\mathrm{d}}$ & $0.30^{\mathrm{d}}$ & $3.43^{\mathrm{a}}$ \\
\hline S.Em \pm & - & 3552.1 & 3551.66 & 0.16 & 0.01 & 0.06 \\
\hline \multicolumn{7}{|l|}{ Factor II: Fertility levels } \\
\hline $\mathrm{F}_{1}: 100 \% \mathrm{RDF}$ & 18602.6 & $242543.1^{\mathrm{c}}$ & $223672.8^{\mathrm{b}}$ & $13.06^{\mathrm{a}}$ & $0.40^{\mathrm{a}}$ & $2.51^{\mathrm{c}}$ \\
\hline $\mathrm{F}_{2}: 150 \% \mathrm{RDF}$ & 23147.6 & $259575.7^{\mathrm{b}}$ & $236463.4^{\mathrm{a}}$ & $11.23^{\mathrm{b}}$ & $0.34^{\mathrm{b}}$ & $2.92^{\mathrm{b}}$ \\
\hline $\mathrm{F}_{3}: 200 \% \mathrm{RDF}$ & 27692.6 & $271692.2^{\mathrm{a}}$ & $244035.4^{\mathrm{a}}$ & $9.94^{\mathrm{c}}$ & $0.29^{c}$ & $3.36^{\mathrm{a}}$ \\
\hline S.Em \pm & - & 4585.7 & 4585.1 & 0.21 & 0.01 & 0.08 \\
\hline \multicolumn{7}{|l|}{ Interaction $(\mathbf{W} \times \mathbf{F})$} \\
\hline $\mathrm{W}_{1} \mathrm{~F}_{1}: 1^{\text {st }}$ week of Oct $+100 \%$ RDF & 18596.7 & $264510.1^{\mathrm{c}-\mathrm{e}}$ & $245942.8^{\mathrm{a}-\mathrm{c}}$ & $14.24^{\mathrm{a}}$ & $0.45^{\mathrm{a}}$ & $2.21^{\mathrm{h}}$ \\
\hline $\mathrm{W}_{1} \mathrm{~F}_{2}: 1^{\text {st }}$ week of Oct $+150 \%$ RDF & 23141.6 & $281676.0^{\mathrm{a}-\mathrm{c}}$ & $258563.8^{\mathrm{ab}}$ & $12.18^{\mathrm{b}}$ & $0.38^{\mathrm{bc}}$ & $2.62^{\mathrm{e}-\mathrm{h}}$ \\
\hline $\mathrm{W}_{1} \mathrm{~F}_{3}: 1^{\text {st }}$ week of Oct $+200 \%$ RDF & 27686.7 & $297515.0^{\mathrm{a}}$ & $269857.8^{\mathrm{a}}$ & $10.76^{\mathrm{cd}}$ & $0.32^{\mathrm{ef}}$ & $3.03^{\mathrm{c}-\mathrm{e}}$ \\
\hline $\mathrm{W}_{2} \mathrm{~F}_{1}: 2^{\text {nd }}$ week of Oct $+100 \% \mathrm{RDF}$ & 18596.7 & $257193.0^{c-e}$ & $238625.7^{\mathrm{b}-\mathrm{d}}$ & $13.85^{\mathrm{a}}$ & $0.44^{\mathrm{a}}$ & $2.28^{\mathrm{gh}}$ \\
\hline $\mathrm{W}_{2} \mathrm{~F}_{2}: 2^{\text {nd }}$ week of Oct $+150 \%$ RDF & 23141.6 & $281176.0^{\mathrm{a}-\mathrm{c}}$ & $258063.7^{\mathrm{ab}}$ & $12.17^{\mathrm{b}}$ & $0.38^{\mathrm{bc}}$ & $2.64^{\mathrm{e}-\mathrm{h}}$ \\
\hline $\mathrm{W}_{2} \mathrm{~F}_{3}: 2^{\text {nd }}$ week of Oct $+200 \% \mathrm{RDF}$ & 27686.7 & $292125.6^{\mathrm{ab}}$ & $264468.4^{\mathrm{ab}}$ & $10.56^{\mathrm{cd}}$ & $0.32^{\mathrm{ef}}$ & $3.03^{\mathrm{c}-\mathrm{e}}$ \\
\hline $\mathrm{W}_{3} \mathrm{~F}_{1}: 3^{\text {rd }}$ week of Oct $+100 \%$ RDF & 18602.6 & $249111.3^{\mathrm{d}-\mathrm{f}}$ & $230544.0^{c-e}$ & $13.41^{\mathrm{a}}$ & $0.42^{\mathrm{ab}}$ & $2.38^{\mathrm{f}-\mathrm{h}}$ \\
\hline $\mathrm{W}_{3} \mathrm{~F}_{2}: 3^{\text {rd }}$ week of Oct $+150 \%$ RDF & 23147.6 & $262982.0^{\text {c-e }}$ & $239869.7^{\mathrm{bc}}$ & $11.38^{\mathrm{bc}}$ & $0.35^{\mathrm{c}-\mathrm{e}}$ & $2.82^{\mathrm{d}-\mathrm{f}}$ \\
\hline $\mathrm{W}_{3} \mathrm{~F}_{3}: 3^{\text {rd }}$ week of Oct $+200 \%$ RDF & 27692.6 & $269802.0^{b-d}$ & $242144.8^{\mathrm{bc}}$ & $10.36^{\mathrm{c}-\mathrm{e}}$ & $0.30^{\mathrm{fg}}$ & $3.35^{\mathrm{bc}}$ \\
\hline $\mathrm{W}_{4} \mathrm{~F}_{1}: 4^{\text {th }}$ week of Oct $+100 \%$ RDF & 18608.5 & $228993.6^{\mathrm{fg}}$ & $210426.3^{\text {ef }}$ & $12.33^{\mathrm{b}}$ & $0.37^{\mathrm{cd}}$ & $2.70^{\mathrm{d}-\mathrm{g}}$ \\
\hline $\mathrm{W}_{4} \mathrm{~F}_{2}: 4^{\text {th }}$ week of Oct $+150 \%$ RDF & 23153.5 & $242888.5^{\text {ef }}$ & $219776.2^{\text {c-e }}$ & $10.51^{\mathrm{cd}}$ & $0.32^{\mathrm{ef}}$ & $3.11^{\mathrm{b}-\mathrm{d}}$ \\
\hline $\mathrm{W}_{4} \mathrm{~F}_{3}: 4^{\text {th }}$ week of Oct $+200 \%$ RDF & 27698.5 & $257974.8^{\mathrm{c}-\mathrm{e}}$ & $230317.5^{\mathrm{ce}}$ & $9.32^{\mathrm{ef}}$ & $0.28^{\mathrm{fg}}$ & $3.53^{\mathrm{ab}}$ \\
\hline $\mathrm{W}_{5} \mathrm{~F}_{1}: 1^{\text {st }}$ week of Nov $+100 \%$ RDF & 18608.5 & $212907.3^{\mathrm{g}}$ & $192825.1^{\mathrm{f}}$ & $11.46^{\mathrm{bc}}$ & $0.33^{\mathrm{d}-\mathrm{f}}$ & $3.02^{\mathrm{c}-\mathrm{e}}$ \\
\hline $\mathrm{W}_{5} \mathrm{~F}_{2}: 1^{\mathrm{st}}$ week of Nov $+150 \% \mathrm{RDF}$ & 23153.5 & $229156.2^{\mathrm{fg}}$ & $206044.0^{\text {ef }}$ & $9.91^{\mathrm{de}}$ & $0.29^{\mathrm{fg}}$ & $3.40^{\mathrm{bc}}$ \\
\hline $\mathrm{W}_{5} \mathrm{~F}_{3}: 1^{\text {st }}$ week of Nov $+200 \% \mathrm{RDF}$ & 27698.5 & $241046.0^{\text {ef }}$ & $213388.7^{\mathrm{d}-\mathrm{f}}$ & $8.71^{\mathrm{f}}$ & $0.26^{\mathrm{g}}$ & $3.85^{\mathrm{a}}$ \\
\hline S.Em \pm & - & 7942.7 & 7941.8 & 0.37 & 0.01 & 0.14 \\
\hline
\end{tabular}


Table 6: Economics of winter maize as influenced by sowing windows and fertility levels

\begin{tabular}{|c|c|c|c|c|}
\hline Treatment & $\begin{array}{l}\text { Cost of } \\
\text { cultivation } \\
\left(\text { USD ha }^{-1}\right)\end{array}$ & $\begin{array}{l}\text { Gross } \\
\text { return } \\
\left(\mathbf{U S D ~ h a}^{-1}\right)\end{array}$ & $\begin{array}{l}\text { Net return } \\
(\text { USD ha-1) }\end{array}$ & B-C ratio \\
\hline \multicolumn{5}{|l|}{ Factor I: Sowing windows } \\
\hline $\mathrm{W}_{1}: 1^{\text {st }}$ week of October & 922 & $2331^{\mathrm{a}}$ & $1409^{\mathrm{a}}$ & $2.53^{\mathrm{a}}$ \\
\hline $\mathrm{W}_{2}: 2^{\text {nd }}$ week of October & 922 & $2293^{\mathrm{ab}}$ & $1371^{\mathrm{a}}$ & $2.49^{\mathrm{a}}$ \\
\hline $\mathrm{W}_{3}: 3^{\text {rd }}$ week of October & 935 & $2158^{\mathrm{b}}$ & $1223^{b}$ & $2.31^{\mathrm{b}}$ \\
\hline $\mathrm{W}_{4}: 4^{\text {th }}$ week of October & 948 & $1977^{\mathrm{c}}$ & $1030^{c}$ & $2.09^{\mathrm{c}}$ \\
\hline $\mathrm{W}_{5}: 1^{\text {st }}$ week of November & 948 & $1795^{\mathrm{d}}$ & $848^{\mathrm{d}}$ & $1.89^{\mathrm{d}}$ \\
\hline S.Em \pm & - & 38.9 & 38.9 & 0.04 \\
\hline \multicolumn{5}{|l|}{ Factor II: Fertility levels } \\
\hline $\mathrm{F}_{1}: 100 \% \mathrm{RDF}$ & 889 & $1991^{\mathrm{b}}$ & $1102^{b}$ & $2.24^{\mathrm{a}}$ \\
\hline $\mathrm{F}_{2}: 150 \% \mathrm{RDF}$ & 935 & $2130^{\mathrm{a}}$ & $1196^{\mathrm{ab}}$ & $2.28^{\mathrm{a}}$ \\
\hline $\mathrm{F}_{3}: 200 \% \mathrm{RDF}$ & 980 & $2211^{\mathrm{a}}$ & $1231^{\mathrm{a}}$ & $2.26^{\mathrm{a}}$ \\
\hline S.Em \pm & - & 50.3 & 50.3 & 0.05 \\
\hline \multicolumn{5}{|l|}{ Interaction $(\mathbf{W} \times \mathbf{F})$} \\
\hline $\mathrm{W}_{1} \mathrm{~F}_{1}: 1^{\text {st }}$ week of Oct $+100 \% \mathrm{RDF}$ & 876 & $2226^{\mathrm{a}-\mathrm{d}}$ & $1350^{\mathrm{ab}}$ & $2.54^{\mathrm{a}}$ \\
\hline $\mathrm{W}_{1} \mathrm{~F}_{2}: 1^{\text {st }}$ week of Oct $+150 \% \mathrm{RDF}$ & 922 & $2338^{a-c}$ & $1416^{\mathrm{a}}$ & $2.55^{\mathrm{a}}$ \\
\hline $\mathrm{W}_{1} \mathrm{~F}_{3}: 1^{\text {st }}$ week of Oct $+200 \% \mathrm{RDF}$ & 968 & $2429^{\mathrm{a}}$ & $1462^{\mathrm{a}}$ & $2.51^{\mathrm{a}}$ \\
\hline $\mathrm{W}_{2} \mathrm{~F}_{1}: 2^{\text {nd }}$ week of Oct $+100 \% \mathrm{RDF}$ & 876 & $2157^{\mathrm{a}-\mathrm{e}}$ & $1281^{a-c}$ & $2.46^{\mathrm{a}}$ \\
\hline $\mathrm{W}_{2} \mathrm{~F}_{2}: 2^{\text {nd }}$ week of Oct $+150 \%$ RDF & 922 & $2330^{\mathrm{a}-\mathrm{c}}$ & $1408^{\mathrm{a}}$ & $2.53^{\mathrm{a}}$ \\
\hline $\mathrm{W}_{2} \mathrm{~F}_{3}: 2^{\text {nd }}$ week of Oct $+200 \% \mathrm{RDF}$ & 968 & $2392^{\mathrm{ab}}$ & $1425^{\mathrm{a}}$ & $2.47^{\mathrm{a}}$ \\
\hline $\mathrm{W}_{3} \mathrm{~F}_{1}: 3^{\text {rd }}$ week of Oct $+100 \% \mathrm{RDF}$ & 889 & $2083^{\mathrm{c}-\mathrm{g}}$ & $1194^{\mathrm{a}-\mathrm{d}}$ & $2.34^{\mathrm{ab}}$ \\
\hline $\mathrm{W}_{3} \mathrm{~F}_{2}: 3^{\text {rd }}$ week of Oct $+150 \% \mathrm{RDF}$ & 935 & $2180^{\mathrm{a}-\mathrm{e}}$ & $1245^{\mathrm{a}-\mathrm{c}}$ & $2.33^{\mathrm{a}-\mathrm{c}}$ \\
\hline $\mathrm{W}_{3} \mathrm{~F}_{3}: 3^{\text {rd }}$ week of Oct $+200 \% \mathrm{RDF}$ & 980 & $2210^{\mathrm{a}-\mathrm{d}}$ & $1230^{\mathrm{a}-\mathrm{c}}$ & $2.25^{\mathrm{a}-\mathrm{c}}$ \\
\hline $\mathrm{W}_{4} \mathrm{~F}_{1}: 4^{\text {th }}$ week of Oct $+100 \% \mathrm{RDF}$ & 902 & $1841^{\mathrm{f}-\mathrm{h}}$ & $940^{\mathrm{d}-\mathrm{f}}$ & $2.04^{\mathrm{c}-\mathrm{e}}$ \\
\hline $\mathrm{W}_{4} \mathrm{~F}_{2}: 4^{\text {th }}$ week of Oct $+150 \%$ RDF & 948 & $1978^{\mathrm{d}-\mathrm{g}}$ & $1031^{\mathrm{c}-\mathrm{e}}$ & $2.09^{b-\mathrm{e}}$ \\
\hline $\mathrm{W}_{4} \mathrm{~F}_{3}: 4^{\text {th }}$ week of Oct $+200 \% \mathrm{RDF}$ & 993 & $2111^{\mathrm{b}-\mathrm{f}}$ & $1118^{\mathrm{b}-\mathrm{e}}$ & $2.12^{\mathrm{b}-\mathrm{d}}$ \\
\hline $\mathrm{W}_{5} \mathrm{~F}_{1}: 1^{\text {st }}$ week of Nov $+100 \%$ RDF & 902 & $1648^{\mathrm{h}}$ & $746^{\mathrm{f}}$ & $1.83^{\mathrm{e}}$ \\
\hline $\mathrm{W}_{5} \mathrm{~F}_{2}: 1^{\mathrm{st}}$ week of Nov $+150 \% \mathrm{RDF}$ & 948 & $1825^{\mathrm{gh}}$ & $878^{\text {ef }}$ & $1.93^{\mathrm{de}}$ \\
\hline $\mathrm{W}_{5} \mathrm{~F}_{3}: 1^{\mathrm{st}}$ week of Nov $+200 \% \mathrm{RDF}$ & 993 & $1914^{\mathrm{e}-\mathrm{h}}$ & $920^{\mathrm{d}-\mathrm{f}}$ & $1.93^{\mathrm{de}}$ \\
\hline S.Em \pm & - & 87.1 & 87.1 & 0.10 \\
\hline
\end{tabular}

Highest values were denoted with ' $a$ ' followed by the next alphabets for lower values $(b, c, d$ etc.). Value denoted by same small letter in the column does not differ significantly at 0.05 level of significance. $(1 \mathrm{USD}=70 \mathrm{INR})$ 

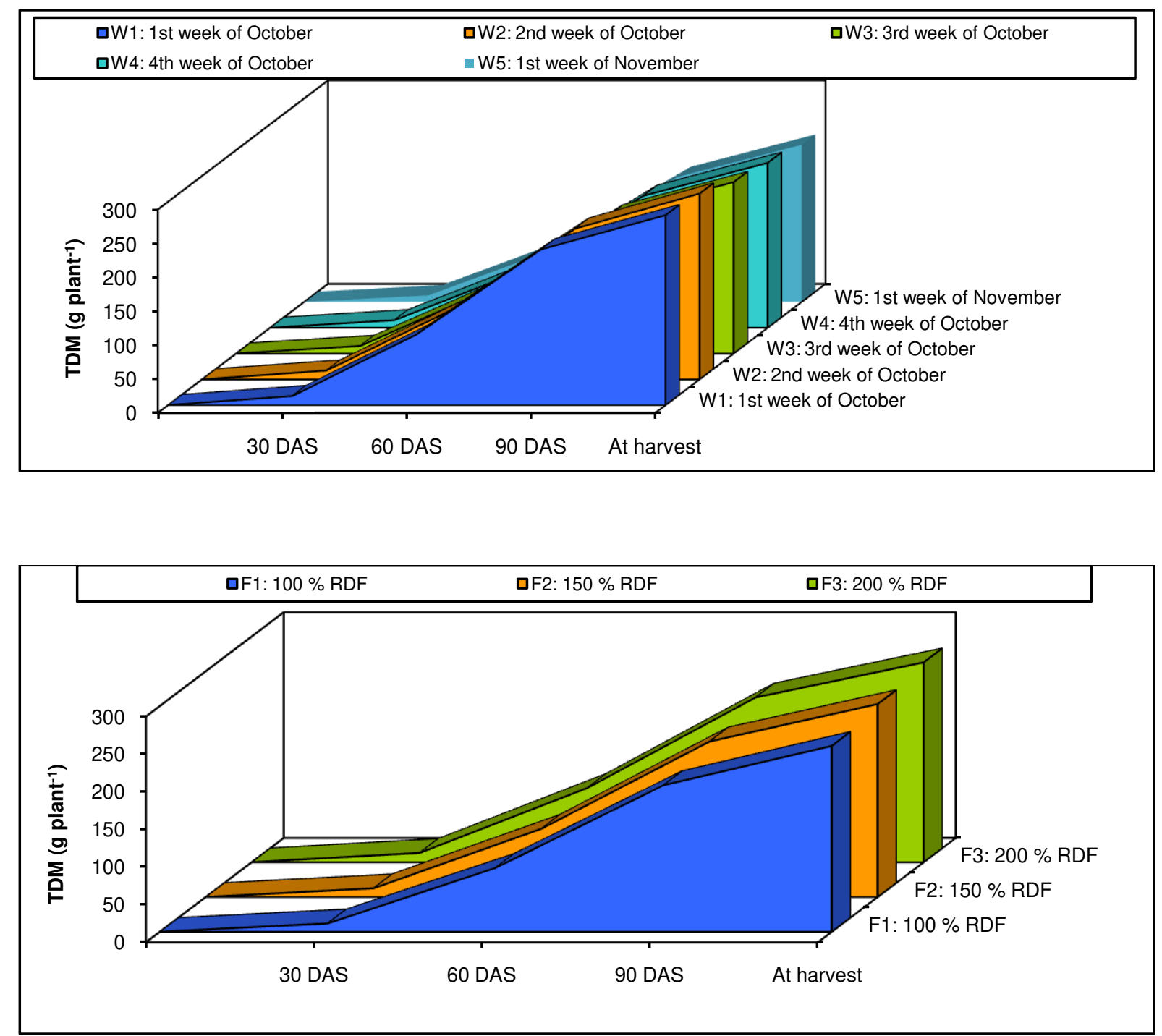

Figure 1b: Total dry matter (TDM) production per plant at different growth stages of winter maize as influenced by fertility

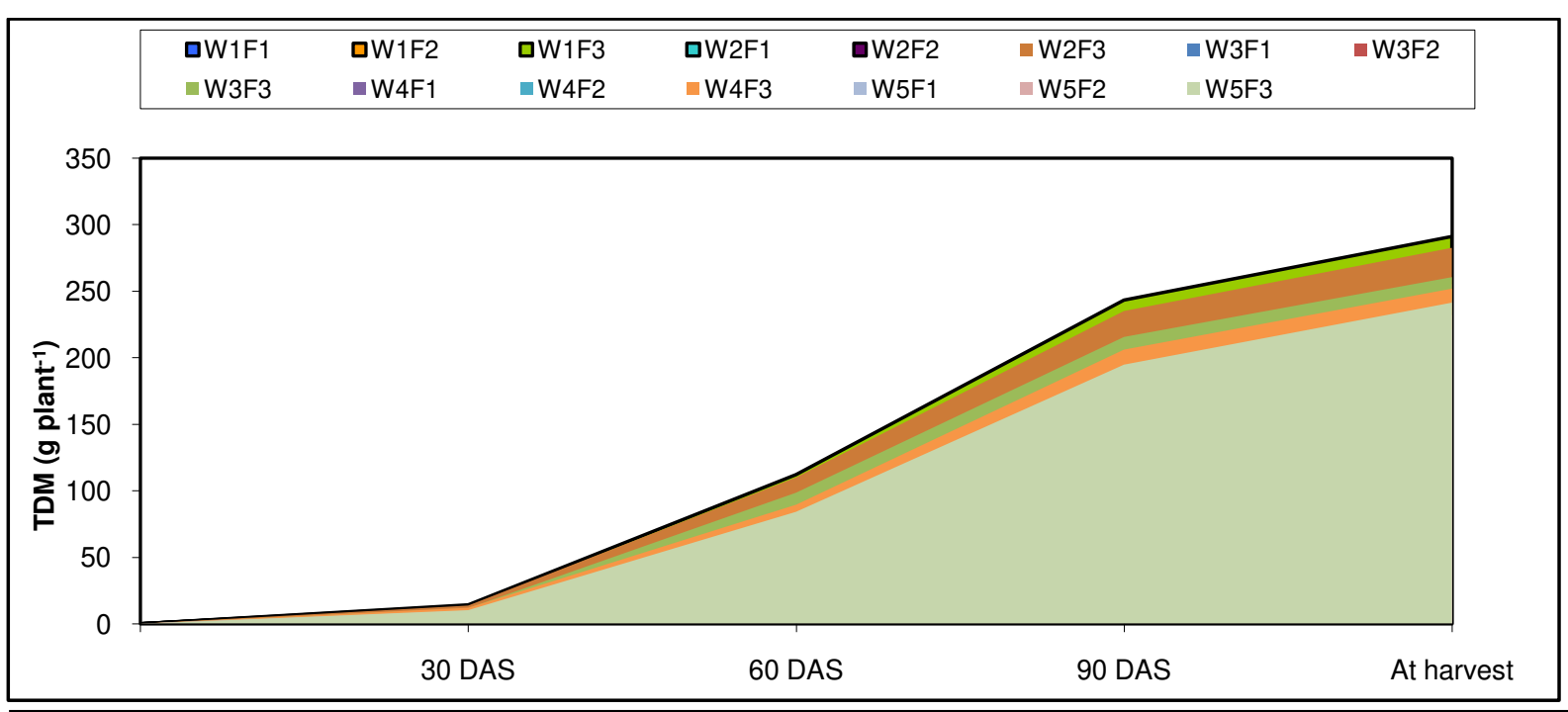

Figure 1c: TDM production per plant at different growth stages of winter maize as influenced by sowing windows and fertility levels 



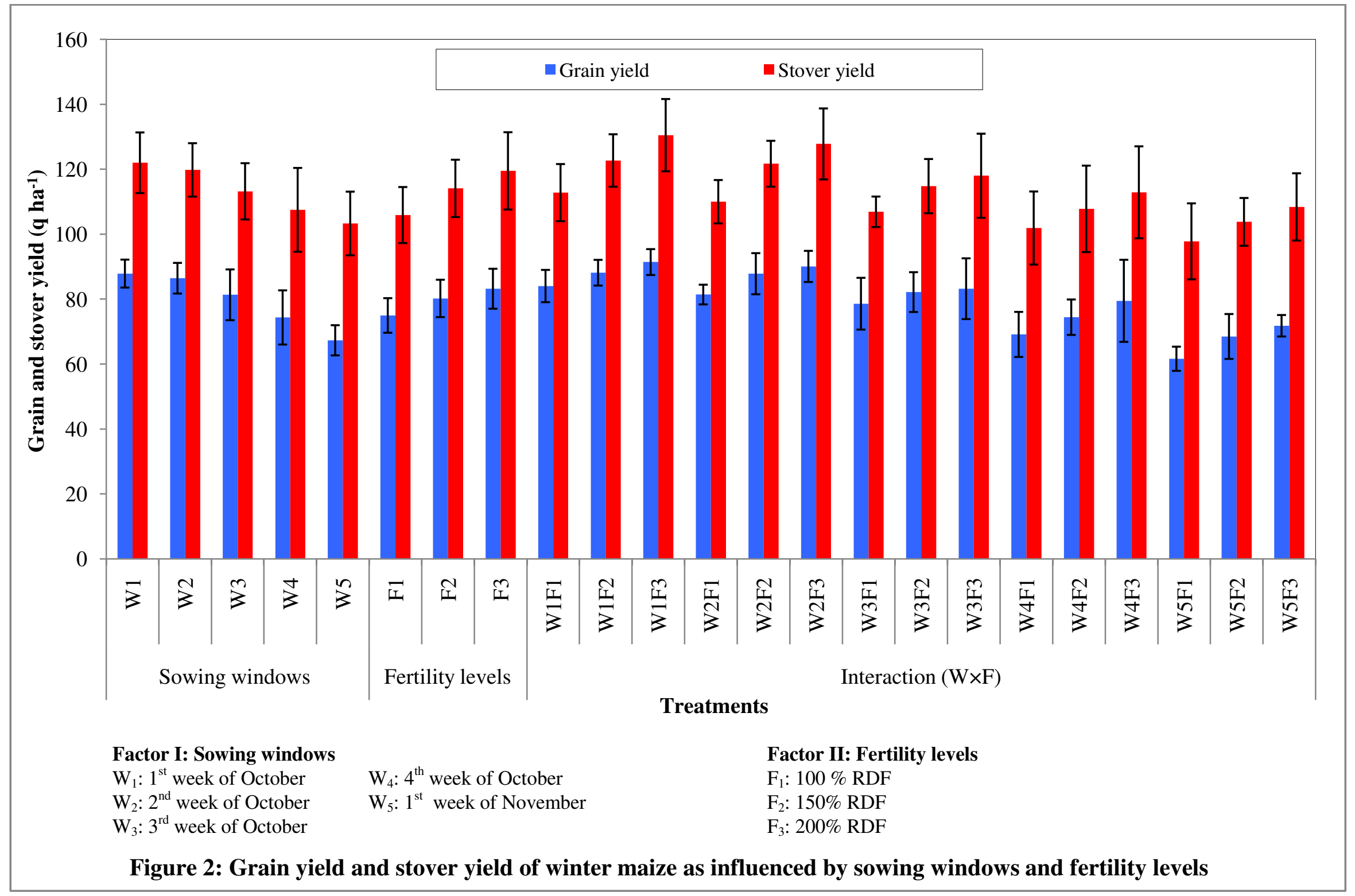




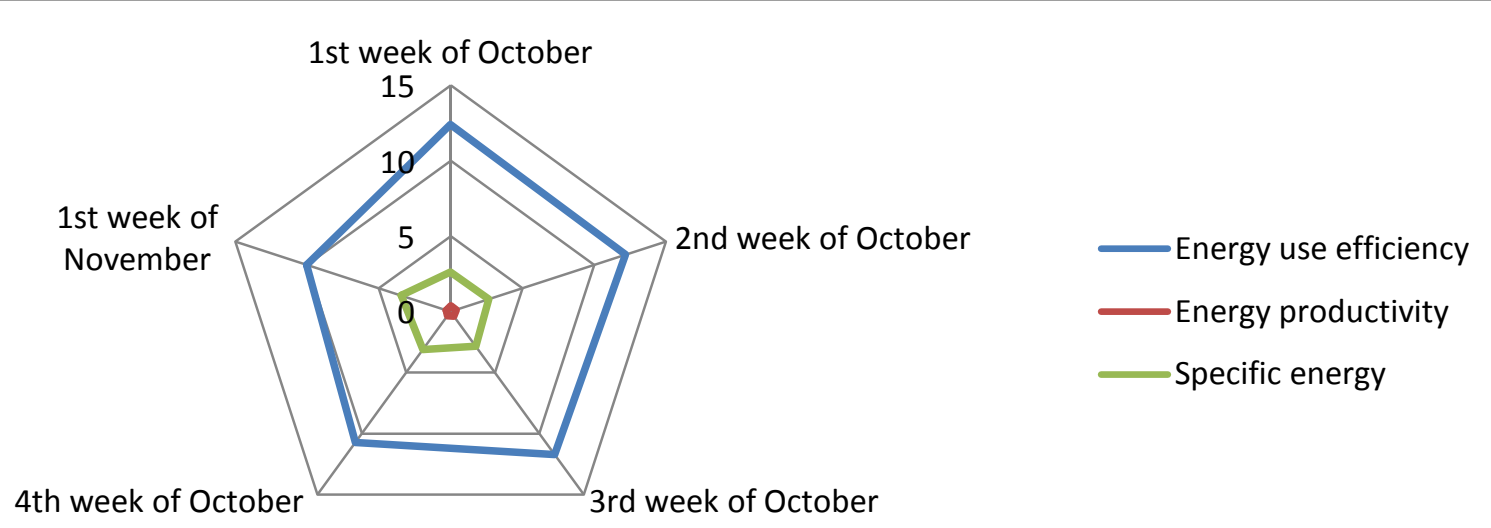

Figure 3a. Radar chart representing multi-criteria assessment for energy use efficiency, energy productivity and specific energy for $1^{\text {st }}, 2^{\text {nd }}, 3^{\text {rd }}, 4^{\text {th }}$ week of October and $1^{\text {st }}$ week of November.

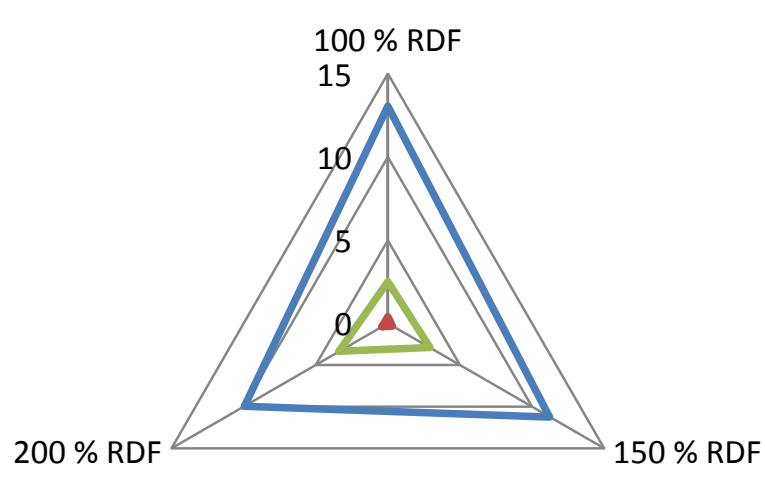

Energy use efficiency

Energy productivity

Specific energy

Figure 3b. Radar chart representing multi-criteria assessment for energy use efficiency, energy productivity and specific energy for $100 \%, 150 \%$ and $200 \%$ RDF. 


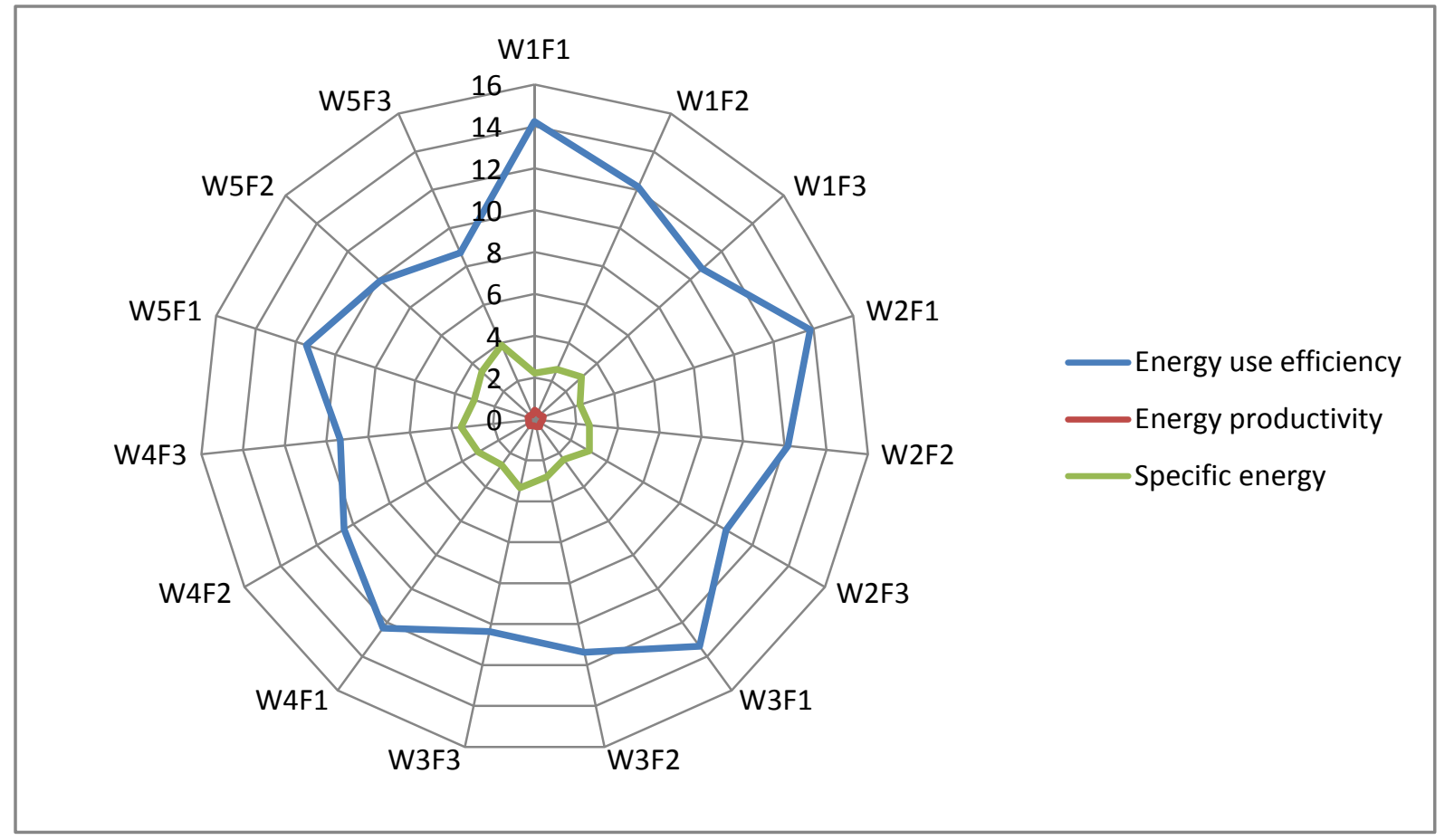

Figure 3c. Radar chart representing multi-criteria assessment for energy use efficiency, energy productivity and specific energy for treatment combinations (sowing windows and fertility levels). 


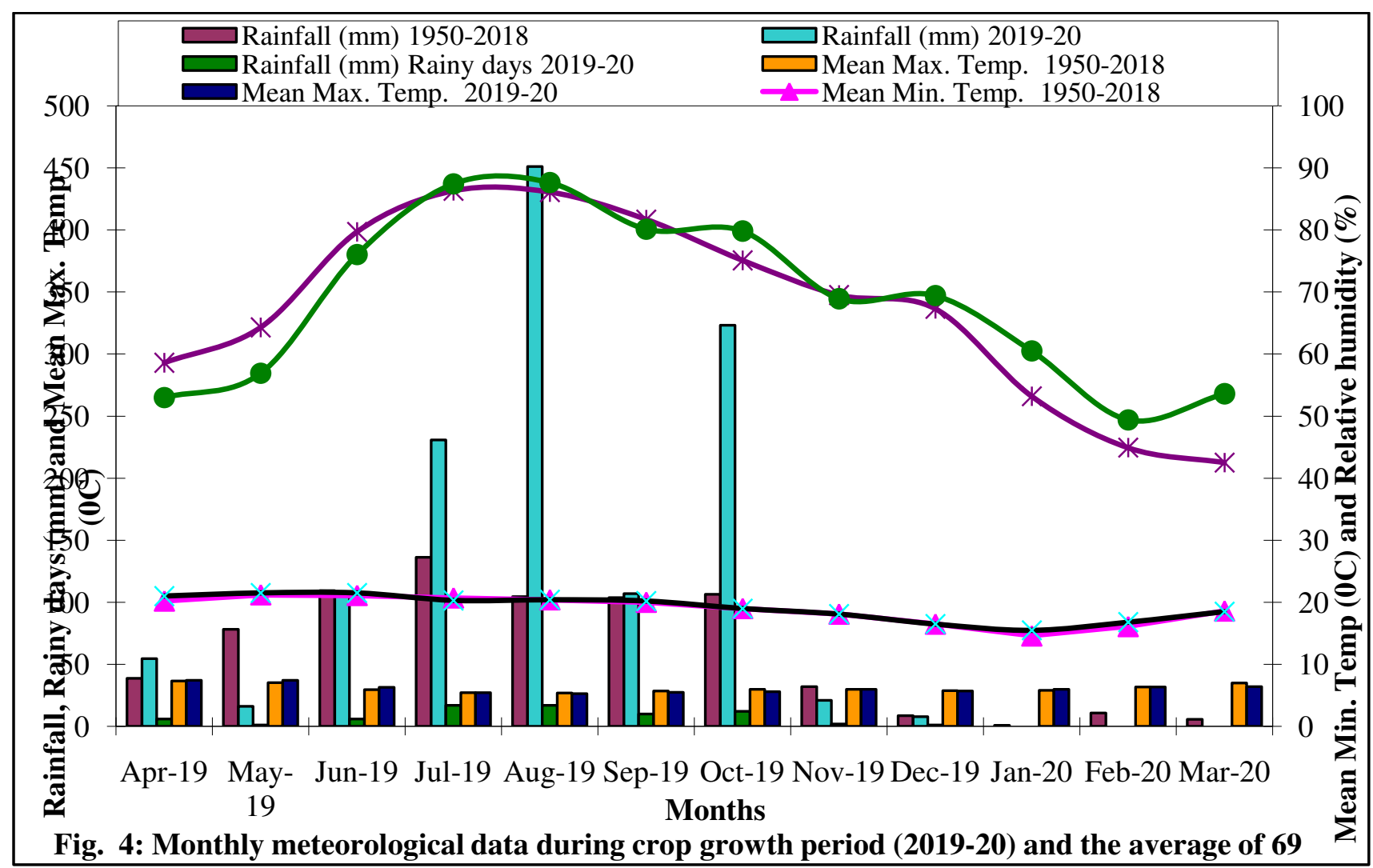




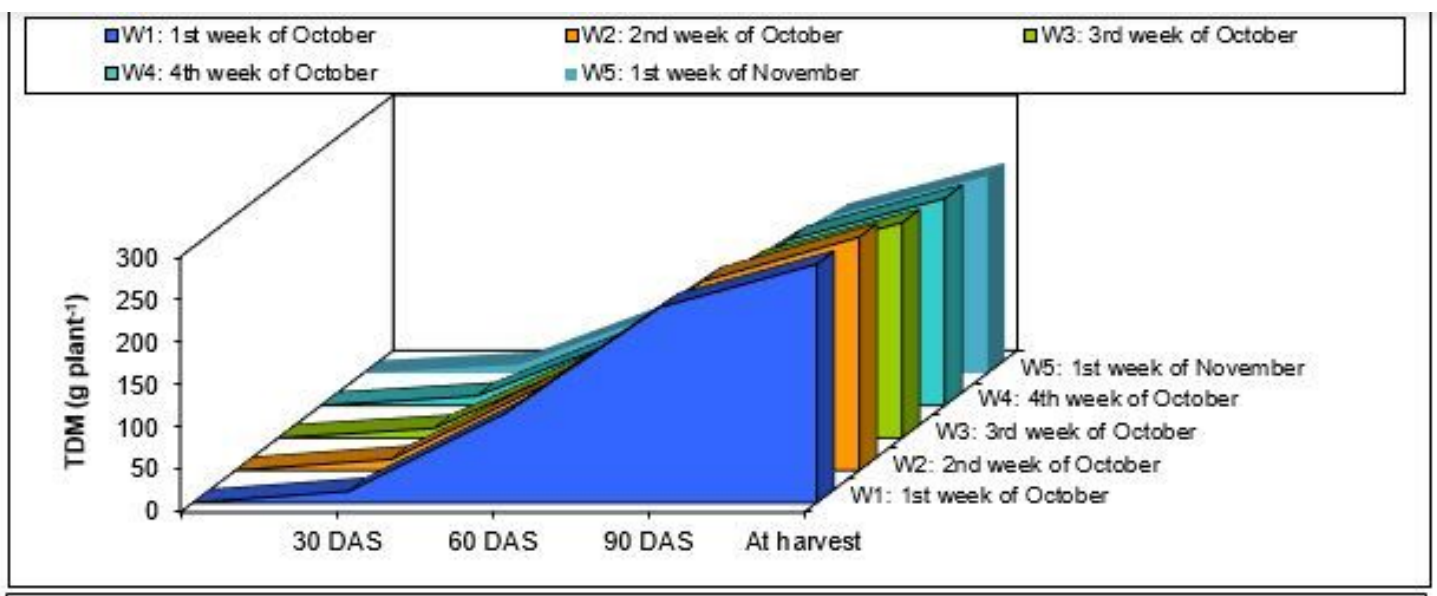

Figure la: Total dry matter (TDM) production per plant at different growth stages of winter maize as influenced by sowing windows

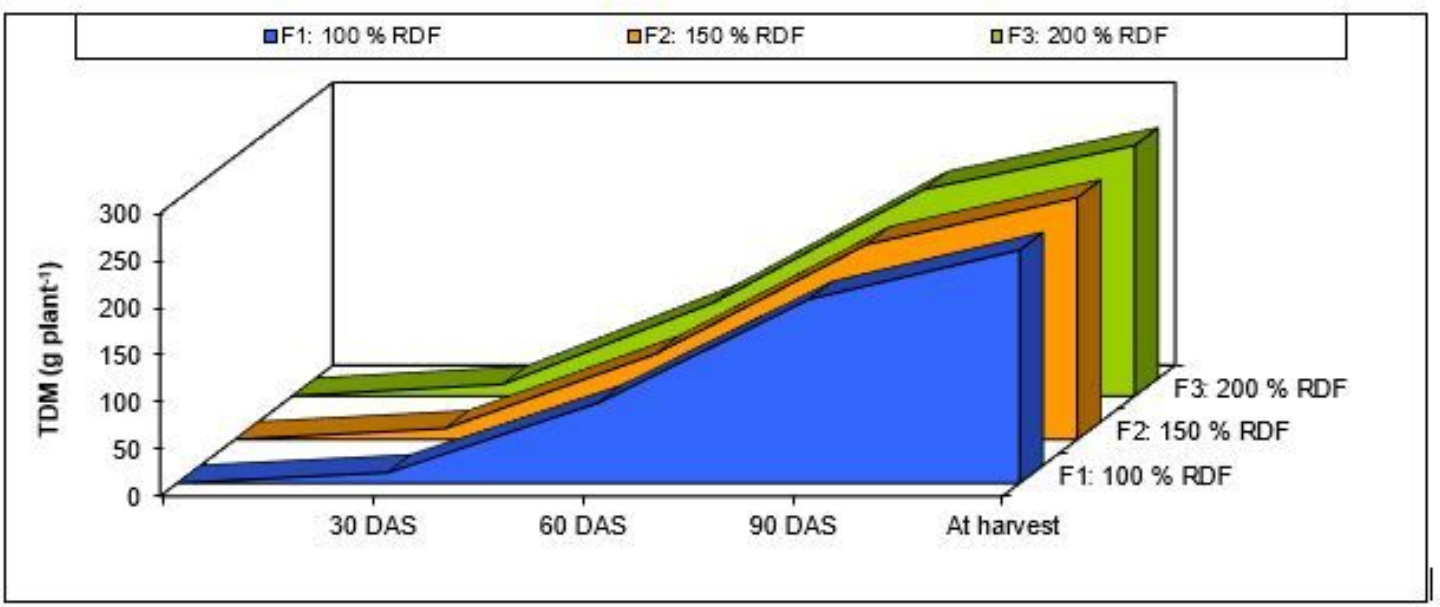

Figure $1 \mathrm{~b}$ : Total dry matter (TDM) production per plant at different growth stages of winter maize as influenced by fertility

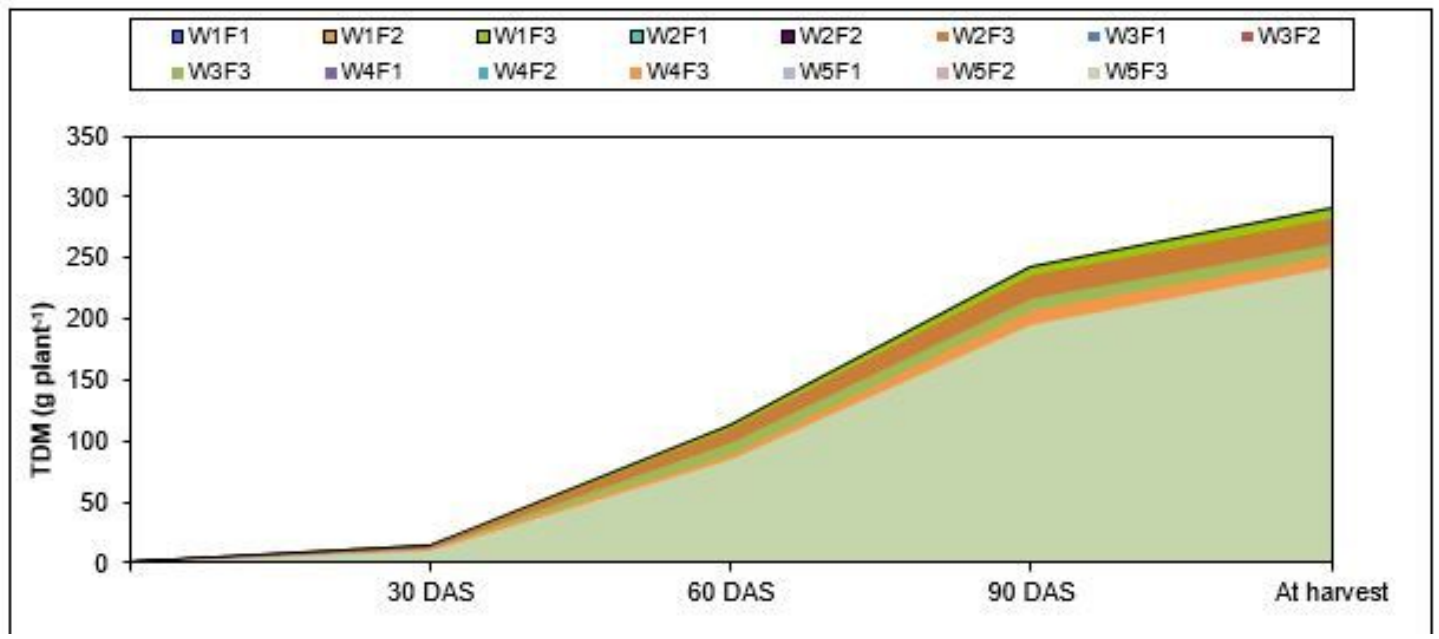

\section{Figure 1}

Figure 1a: Total dry matter (TDM) production per plant at different growth stages of winter maize as influenced by sowing windows. Figure 1b: Total dry matter (TDM) production per plant at different growth 
stages of winter maize as influenced by fertility levels. Figure 1c: TDM production per plant at different growth stages of winter maize as influenced by sowing windows and fertility levels .

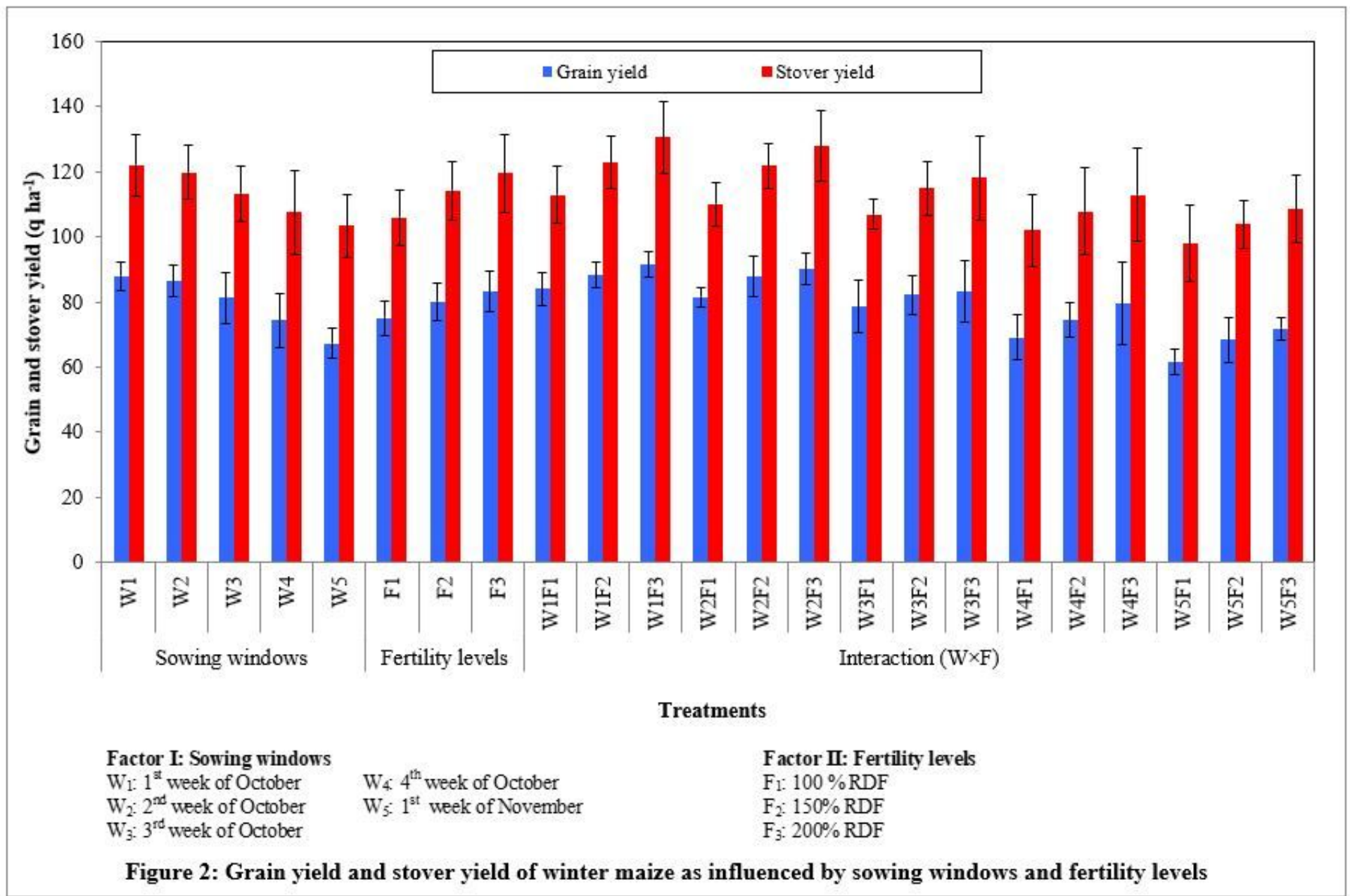

Figure 2

Grain yield and stover yield of winter maize as influenced by sowing windows and fertility levels 


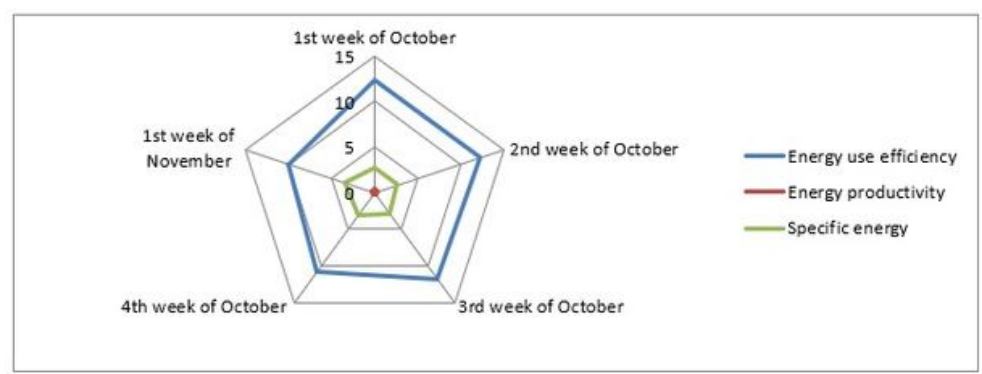

Figure 3a. Radar chart representing multi-criteria assessment for energy use efficiency, energy productivity and specific energy for $1^{\text {st }}, 2^{\text {nd }}, 3^{\text {rd }}, 4^{\text {th }}$ week of October and $1^{\text {st }}$ week of November.

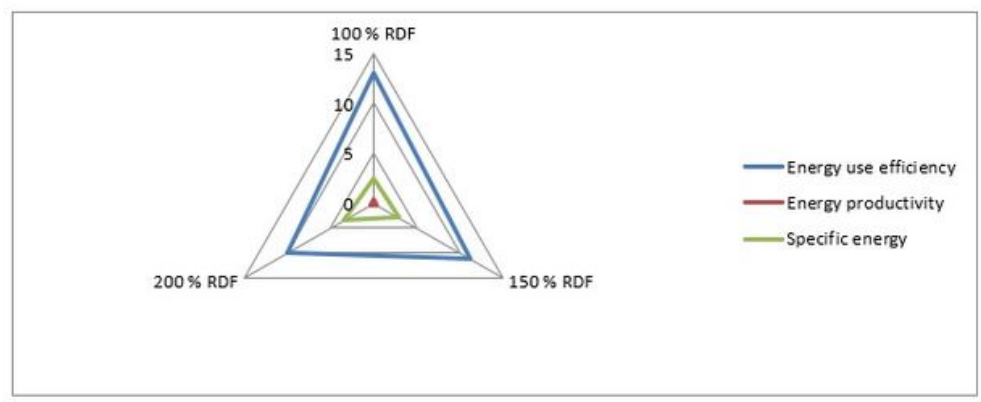

Figure 3b. Radar chart representing multi-criteria assessment for energy use efficiency, energy productivity and specific energy for $100 \%, 150 \%$ and $200 \%$ RDF.

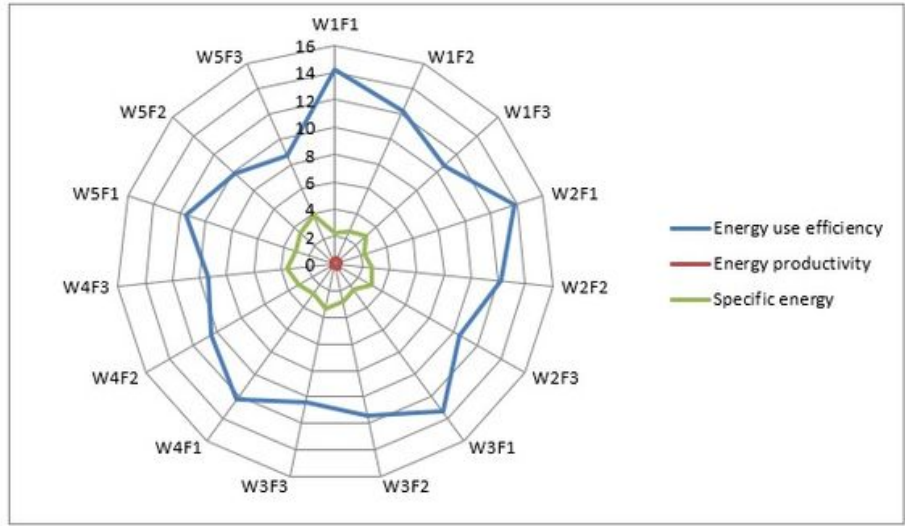

Figure 3c. Radar chart representing multi-criteria assessment for energy use efficiency, energy productivity and specific energy for treatment combinations (sowing windows and fertility levels).

\section{Figure 3}

Figure 3a. Radar chart representing multi-criteria assessment for energy use efficiency, energy productivity and specific energy for 1st, 2nd, 3rd, 4th week of October and 1st week of November. Figure $3 \mathrm{~b}$. Radar chart representing multi-criteria assessment for energy use efficiency, energy productivity and specific energy for $100 \%, 150 \%$ and $200 \%$ RDF. Figure 3c. Radar chart representing multi-criteria assessment for energy use efficiency, energy productivity and specific energy for treatment combinations (sowing windows and fertility levels).

\section{Supplementary Files}

This is a list of supplementary files associated with this preprint. Click to download.

- Tabelsrevised.docx 